\title{
Trypsin enhances SARS-CoV-2 infection by facilitating viral entry
}

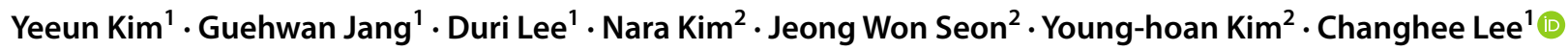

Received: 17 September 2021 / Accepted: 10 November 2021 / Published online: 26 January 2022

(c) The Author(s), under exclusive licence to Springer-Verlag GmbH Austria, part of Springer Nature 2021

\begin{abstract}
Coronaviruses infect cells by cytoplasmic or endosomal membrane fusion, driven by the spike (S) protein, which must be primed by proteolytic cleavage at the S1/S2 furin cleavage site (FCS) and the S2' site by cellular proteases. Exogenous trypsin as a medium additive facilitates isolation and propagation of several coronaviruses in vitro. Here, we show that trypsin enhances severe acute respiratory syndrome coronavirus 2 (SARS-CoV-2) infection in cultured cells and that SARS-CoV-2 enters cells via either a non-endosomal or an endosomal fusion pathway, depending on the presence of trypsin. Interestingly, trypsin enabled viral entry at the cell surface and led to more efficient infection than trypsin-independent endosomal entry, suggesting that trypsin production in the target organs may trigger a high level of replication of SARS-CoV-2 and cause severe tissue injury. Extensive syncytium formation and enhanced growth kinetics were observed only in the presence of exogenous trypsin when cell-adapted SARS-CoV-2 strains were tested. During 50 serial passages without the addition of trypsin, a specific R685S mutation occurred in the S1/S2 FCS $\left({ }^{681}\right.$ PRRAR $^{685}$ ) that was completely conserved but accompanied by several mutations in the $\mathrm{S} 2$ fusion subunit in the presence of trypsin. These findings demonstrate that the S1/S2 FCS is essential for proteolytic priming of the S protein and fusion activity for SARS-CoV-2 entry but not for viral replication. Our data can potentially contribute to the improvement of SARS-CoV-2 production for the development of vaccines or antivirals and motivate further investigations into the explicit functions of cell-adaptation-related genetic drift in SARS-CoV-2 pathogenesis.
\end{abstract}

\section{Introduction}

In December 2019, an outbreak of mysterious pneumonia was reported in Wuhan, Hubei province, China [1, 2]. A novel coronavirus, called severe acute respiratory syndrome coronavirus 2 (SARS-CoV-2), which is closely related to SARS-CoV-1, was detected in patients and subsequently identified as the causative agent of the new respiratory disease in January $2020[2,3]$. SARS-CoV-2 causes coronavirus disease 2019 (COVID-19), which was declared a

Handling Editor: Sheela Ramamoorthy.

Yeeun Kim and Guehwan Jang contributed equally to this work and share co-first authorship.

Changhee Lee

changhee@gnu.ac.kr

1 College of Veterinary Medicine and Virus Vaccine Research Center, Gyeongsang National University, Jinju 52828, Republic of Korea

2 Gyungbuk Veterinary Service Laboratory, Daegu 41405, Republic of Korea global pandemic on March 11, 2020. The rapid national and international spread of SARS-CoV-2 has threatened human health and led to a global economic recession [4].

SARS-CoV-2 is the seventh human coronavirus that has been identified, and it belongs to the subgenus Sarbecovirus of the genus Betacoronavirus in the family Coronaviridae [5]. SARS-CoV-2 is a large, enveloped RNA virus that possesses a single-stranded positive-sense RNA genome of approximately $30 \mathrm{~kb}$. The genome of SARS-CoV-2 encodes 16 nonstructural proteins (nsp1-nsp16); four canonical coronaviral structural proteins, named spike (S), envelope (E), membrane $(\mathrm{M})$, and nucleocapsid $(\mathrm{N})$ proteins; and several accessory proteins [6]. The external S protein anchored on the viral envelope binds to the angiotensin-converting enzyme 2 (ACE2) receptor to mediate viral entry into host cells during SARS-CoV-2 infection [7,8].

Like those of other coronaviruses, the $\mathrm{S}$ protein of SARSCoV-2 can be functionally divided into two subunits ( $\mathrm{S} 1$ and S2) that harbor the receptor-binding domain and the fusion domain, respectively [9]. In general, coronaviruses enter target cells via either cytoplasmic or endosomal membrane fusion, which is a primary determinant of viral infectivity. 
Efficient proteolytic priming of S at the $\mathrm{S} 1 / \mathrm{S} 2$ and $\mathrm{S} 2$ ' sites is essential for exposing the fusion peptide and mediating membrane fusion to complete the viral entry process [10]. To accomplish S protein priming, SARS-CoV-2 uses either endosomal cysteine proteases or transmembrane protease serine 2 (TMPRSS2) [10]. In an infection experiment with SARS-CoV-2, a Vero E6 cell line overexpressing TMPRSS2 produced a higher viral titer than the parental cells, indicating the importance of this protease for the fusion capacity and infectivity of SARS-CoV-2 [11]. Trypsin is another protease that has been shown to facilitate the fusion and infection of human and animal coronaviruses [12-15] and is essential for the propagation of swine enteric coronaviruses such as porcine epidemic diarrhea virus (PEDV) and porcine deltacoronavirus (PDCoV) in vitro [16-20]. Therefore, we investigated whether exogenous trypsin treatment enhances SARS-CoV-2 infection in Vero E6 cells and how it promotes viral replication in cultured cells.

\section{Materials and methods}

\section{Cells and virus}

Vero E6 cells (ATCC CRL-1586) were cultured in highglucose Dulbecco's modified Eagle's medium (DMEM; Invitrogen, Carlsbad, CA) supplemented with $10 \%$ fetal bovine serum (FBS, Invitrogen) and penicillin-streptomycin (100x; Invitrogen). The cells were maintained at $37^{\circ} \mathrm{C}$ in an atmosphere of humidified air containing $5 \% \mathrm{CO}_{2}$. The SARS-CoV-2 KCDC03 strain (BetaCoV/South Korea/ KCDC03/2020) was provided by the Korea Centers for Disease Control and Prevention (KCDC) and propagated in Vero E6 cells as described previously [21]. Virus stock was prepared from KCDC03-infected Vero E6 cell cultures by freezing and thawing as described previously $[19,22]$. The clarified supernatants were aliquoted and stored at $-80^{\circ} \mathrm{C}$ as the 'passage $2(\mathrm{P} 2)^{\prime}$ 'viral stock for the next passage. In the same manner, 50 serial passages were performed in
Vero E6 cells. The titers of SARS-CoV-2 were measured by limiting dilution on Vero E6 cells in triplicate under the indicated conditions, and the $50 \%$ tissue culture infectious dose $\left(\mathrm{TCID}_{50}\right)$ per ml was calculated as described below. All virus infection experiments were conducted in a biosafety level 3 facility at the Gyeongbuk Veterinary Service Laboratory according to the KCDC laboratory biosafety guidelines.

\section{Reagents and antibody}

Trypsin was obtained from USB (Cleveland, $\mathrm{OH}$ ). Elastase and the lysosomal acidification inhibitor bafilomycin A1 (BafA1) were purchased from Sigma-Aldrich (St. Louis, MO). Trypsin and elastase were dissolved in distilled water. BafA1 was dissolved in dimethyl sulfoxide (DMSO). All reagents were used at the indicated concentrations in DMEM. The Alexa Fluor 488-conjugated goat anti-mouse $\mathrm{IgG}$ secondary antibody was obtained from Invitrogen.

\section{Monoclonal antibody production}

The SARS-CoV-2 N gene was amplified by RT-PCR using a specific primer set (forward primer, 5'-GCCGCATATGTC TGATAATGGACCCC-3'; reverse primer, 5'- CTTCCTCGA GGGCCTGAGTTGAGTC-3') and inserted into the pET30a expression vector (Life Science Research, Millstone, NJ). The recombinant $\mathrm{N}$ protein was expressed in E. coli BL21 (DE3) transformed with pET30a-N under isopropyl- $\beta$-Dthiogalactopyranoside induction as described previously [23]. After centrifugation and ultrasonication, the rN protein was purified using a HiTrap TALON crude column (GE Healthcare, Piscataway, NJ) according to the manufacturer's instructions. The purified protein was concentrated using Amicon Ultra centrifugal filters (30 kDa MWCO; Millipore, Billerica, MA), and the final product was used as the antigen. SARS-CoV-2 N-specific monoclonal antibodies (MAbs) were produced as described previously [23]. Fourweek-old female BALB/c mice were immunized four times with $100 \mu \mathrm{g}$ of antigen emulsified in Freund's complete (first
Table 1 Cell viability measured by MTT assay

\begin{tabular}{|c|c|c|c|c|c|}
\hline \multicolumn{2}{|l|}{ Trypsin } & \multicolumn{2}{|l|}{ Elastase } & \multicolumn{2}{|l|}{ BafA1 } \\
\hline $\begin{array}{l}\text { Concentration } \\
(\mu \mathrm{g} / \mathrm{ml})\end{array}$ & $\%$ Cell viability ${ }^{\mathrm{a}}$ & $\begin{array}{l}\text { Concentration } \\
(\mu \mathrm{g} / \mathrm{ml})\end{array}$ & $\%$ Cell viability & $\begin{array}{l}\text { Concentra- } \\
\text { tion }(\mu \mathrm{M})\end{array}$ & $\%$ Cell viability \\
\hline Control & $100.00 \pm 0.012$ & Control & $100.00 \pm 0.019$ & Control & $100.00 \pm 0.014$ \\
\hline 1.25 & $103.10 \pm 0.013$ & 5 & $99.16 \pm 0.018$ & 0.1 & $108.08 \pm 0.014$ \\
\hline 2.5 & $102.44 \pm 0.006$ & 10 & $98.93 \pm 0.037$ & 0.5 & $100.54 \pm 0.005$ \\
\hline 5 & $100.64 \pm 0.021$ & 50 & $65.03 \pm 0.025$ & 1 & $83.88 \pm 0.025$ \\
\hline 10 & $98.18 \pm 0.008$ & 100 & $63.22 \pm 0.022$ & 5 & $80.13 \pm 0.028$ \\
\hline 50 & $93.77 \pm 0.011$ & 500 & $55.43 \pm 0.039$ & 10 & $75.21 \pm 0.006$ \\
\hline 100 & $91.02 \pm 0.019$ & 1000 & $42.05 \pm 0.030$ & 20 & $69.63 \pm 0.017$ \\
\hline
\end{tabular}

${ }^{\mathrm{a}}$ All values are expressed as the mean $\pm \operatorname{SDM}(n=3$, in duplicate $)$ 
A
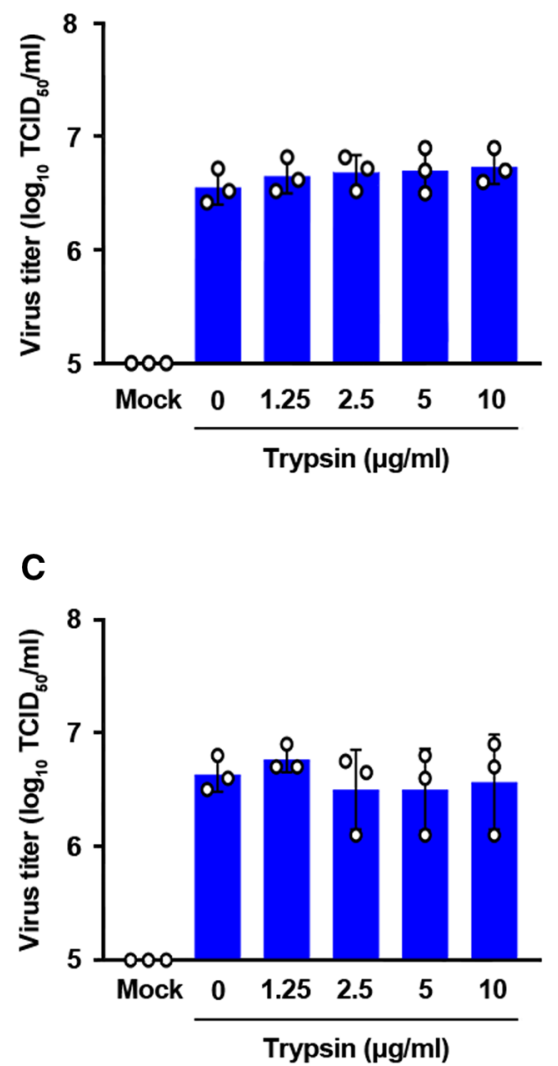

E

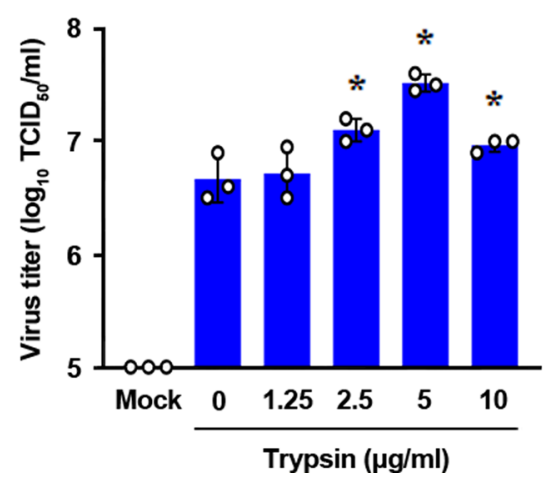

B

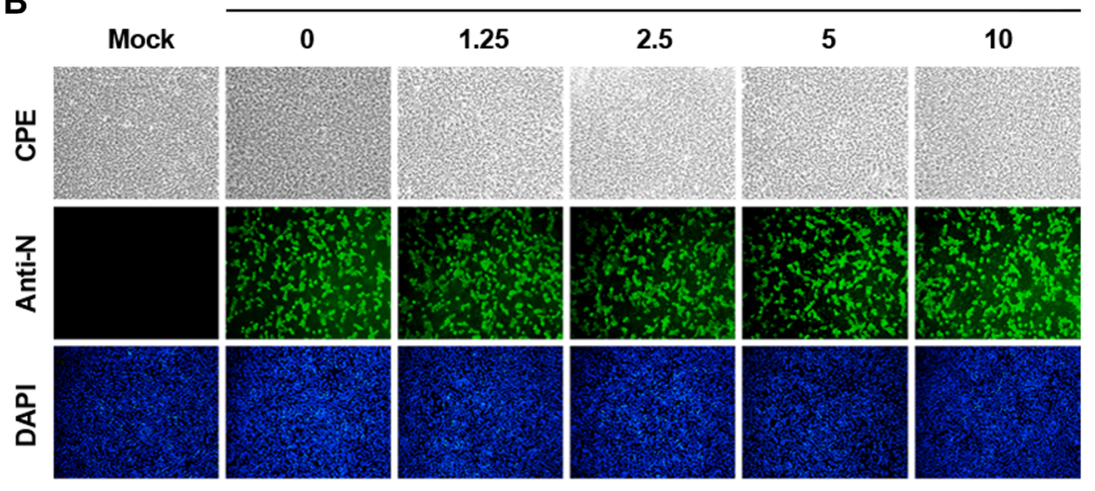

$\mathbf{F}$
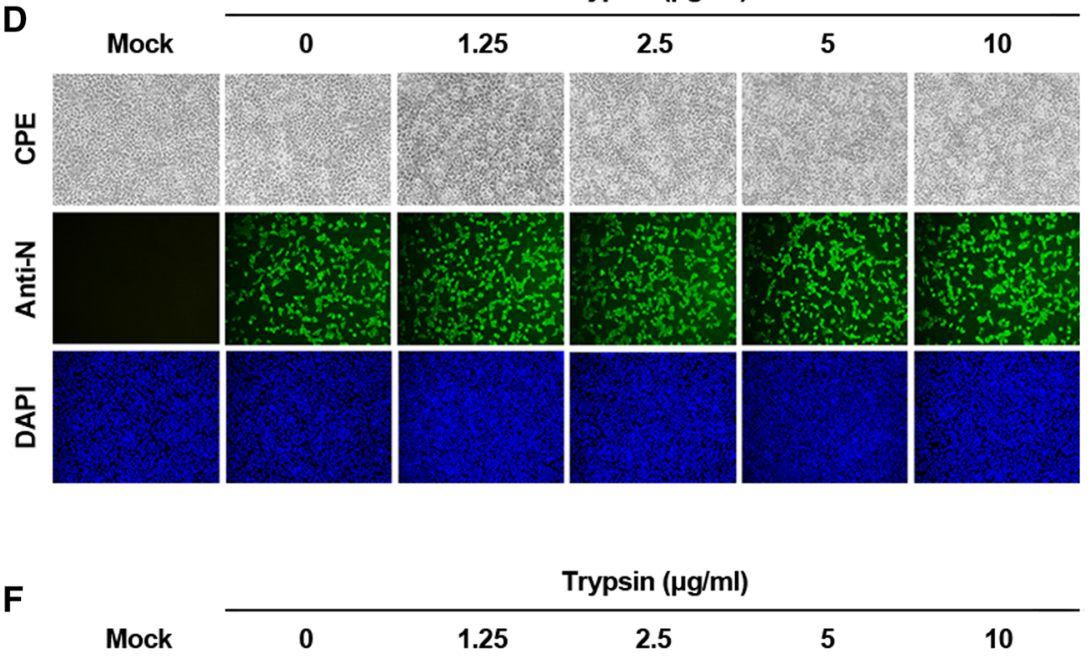

$\operatorname{Trypsin}(\mu \mathrm{g} / \mathrm{ml})$

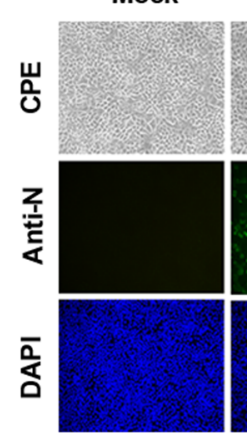

2.5

5

10

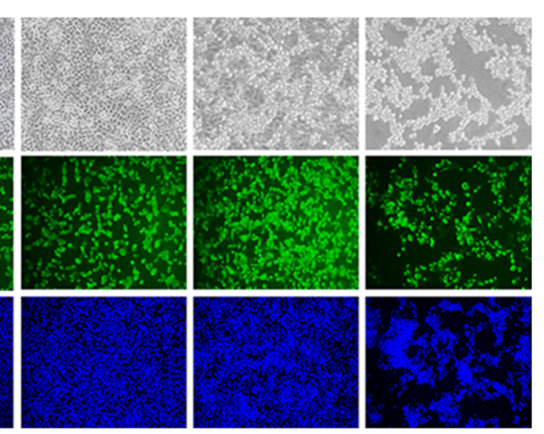

Fig. 1 Trypsin-mediated enhancement of SARS-CoV-2 infection in cultured cells. (A and B) Vero E6 cells were preincubated with trypsin for $1 \mathrm{~h}$ before infection and then mock infected or infected with SARS-CoV-2 (P3) at an MOI of 1 for $1 \mathrm{~h}$ without trypsin addition. The virus-infected cells were then maintained in the absence of trypsin. (C and D) Vero E6 cells were mock infected or infected with SARS-CoV-2 (P3) at an MOI of 1 for $1 \mathrm{~h}$ in the presence of trypsin. The virus-infected cells were then maintained in the absence of trypsin. (E and F) Vero E6 cells were mock infected or infected with SARS-CoV-2 (P3) at an MOI of 1 for $1 \mathrm{~h}$ without trypsin addition. The virus-infected cells were then maintained in the presence of trypsin. The virus supernatants were collected at $24 \mathrm{hpi}$, and viral titers were determined (A, C, and E). SARS-CoV-2-specific CPE was monitored daily, and cells were photographed at 24 hpi using an inverted microscope at a magnification of $200 \times$ (top panels). For immunostaining, infected cells were fixed at $24 \mathrm{hpi}$ and incubated with an MAb against the SARS-CoV-2 N protein, followed by incubation with Alexa green-conjugated goat anti-mouse secondary antibody (middle panels). The cells were then counterstained with DAPI (bottom panels) and examined under a fluorescence microscope at $200 \times$ magnification (B, D, and F). The values shown are the mean of three independent experiments, and error bars show the SDM. *, $P=0.001$ to 0.05 
injection) or incomplete adjuvant (Sigma, St. Louis, MO) at 1 -week intervals. Mouse splenocytes were fused with SP2/0 myeloma cells using 50\% polyethylene glycol 1500 (Roche Diagnostics, Mannheim, Germany). The supernatant of the hybridomas was screened by indirect enzyme-linked immunosorbent assay (ELISA) and immunofluorescence assay as described previously [23]. The positive hybridomas secreting SARS-CoV-2 N-specific MAbs were subcloned three times by limiting dilution and maintained in RPMI 1640 medium (Invitrogen) supplemented with 10\% FBS, penicillin-streptomycin (100×), and $10 \mathrm{mM}$ HEPES (Invitrogen).

\section{Cell viability assay}

The cytotoxic effects of all reagents used in this study were analyzed using a colorimetric 3-(4,5-dimethylthiazol-2-yl)2,5-diphenyltetrazolium bromide (MTT) assay (SigmaAldrich) to detect cell viability as described previously [24]. Briefly, Vero E6 cells were grown at $1 \times 10^{4}$ cells/well in a 96-well tissue culture plate and treated with each chemical for $24 \mathrm{~h}$. After incubation, $50 \mu \mathrm{l}$ of MTT solution $(1.1 \mathrm{mg} /$ $\mathrm{ml})$ was added to each well, and the samples were incubated for an additional $4 \mathrm{~h}$. The supernatant was then removed from each well, followed by the addition of $150 \mu$ l of DMSO to dissolve the colored formazan crystals produced by MTT. The absorbance of the solution was measured at $540 \mathrm{~nm}$ using an ELISA plate reader. All MTT assays were performed in triplicate.

\section{Virus titration}

Vero E6 cells were infected with SARS-CoV-2 in the presence or absence of each protease. The culture supernatant was collected at different time points $(3,6,12,24,36,48$, 60 , and $72 \mathrm{hpi}$ ) and stored at $-80^{\circ} \mathrm{C}$. The SARS-CoV-2 titer was measured by limiting dilution on Vero E6 cells in triplicate, and the $\mathrm{TCID}_{50}$ per $\mathrm{ml}$ was calculated using the ReedMuench method [25].

A
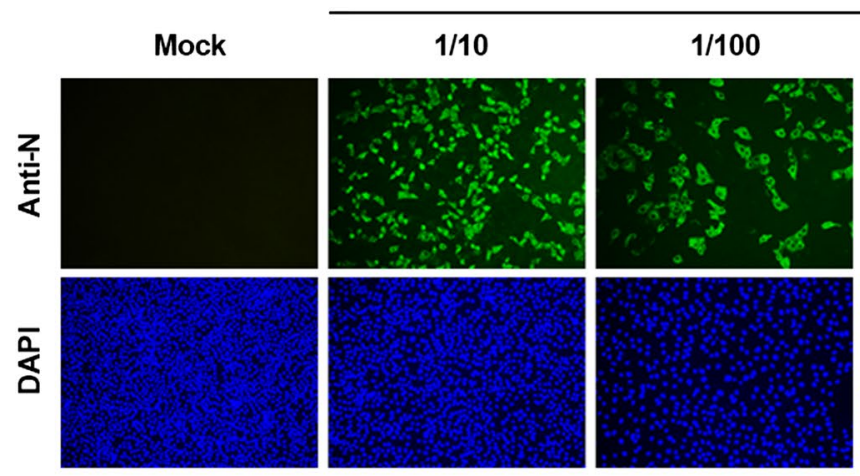

Virus dilution

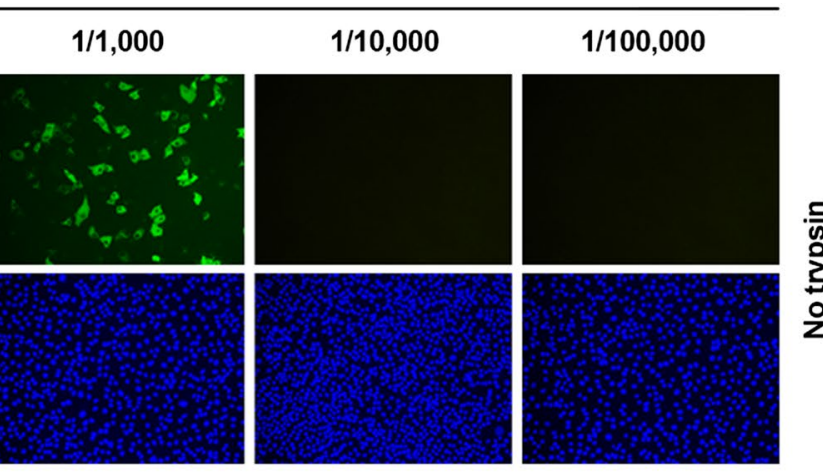

B
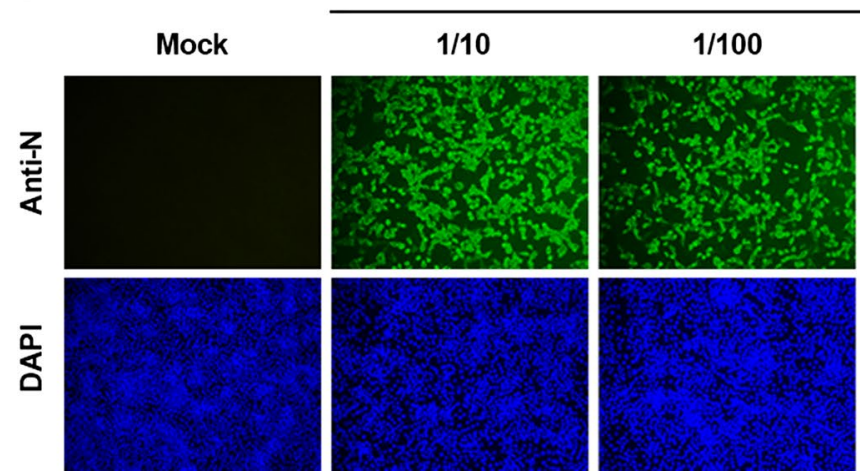

Virus dilution

$1 / 1,000$
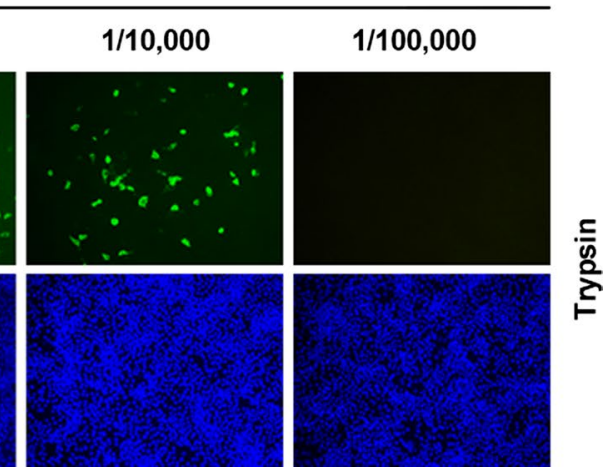

Fig. 2 Comparison of SARS-CoV-2 production in the presence and absence of trypsin. Vero E6 cells were mock infected or infected with tenfold serially diluted SARS-CoV-2 and further cultivated in the presence (A) or absence (B) of trypsin. The virus-infected cells were fixed at $24 \mathrm{hpi}$ and incubated with an MAb against the SARS-CoV-2

$\mathrm{N}$ protein, followed by incubation with Alexa green-conjugated goat anti-mouse secondary antibody (top panels). The cells were then counterstained with DAPI (bottom panels) and examined under a fluorescence microscope at $200 \times$ magnification. 


\section{Immunofluorescence assay (IFA)}

Vero E6 cells grown in 96-well tissue culture plates were mock infected or infected with SARS-CoV-2 (P3) at a multiplicity of infection (MOI) of 1 for $1 \mathrm{~h}$ and cultured under the indicated conditions. At $24 \mathrm{~h}$ postinfection (hpi), SARSCoV-2-infected cells were fixed with $4 \%$ paraformaldehyde for $10 \mathrm{~min}$ at room temperature and permeabilized with $0.2 \%$ Triton X-100 in PBS at room temperature for $10 \mathrm{~min}$. The cells were blocked with $1 \%$ bovine serum albumin in PBS at room temperature for $30 \mathrm{~min}$ and then stained with the SARS-CoV-2 N-specific MAb. After washing five times in PBS, the cells were incubated at room temperature for $1 \mathrm{~h}$ with the corresponding Alexa Fluor-conjugated secondary antibodies, followed by counterstaining with 4',6-diamidino2-phenylindole (DAPI; Sigma-Aldrich). The coverslips were mounted on glass microscope slides in a mounting buffer, and the stained cells were visualized under a Leica DM IL LED fluorescence microscope (Leica, Wetzlar, Germany).

\section{Time course of trypsin treatment}

Vero E6 cells were infected with SARS-CoV-2 at an MOI of 1. At $0,1,2,4,6$, and $10 \mathrm{hpi}$, trypsin was added to achieve the indicated final concentration over the remainder of the time course of the experiment. The culture supernatants were harvested at 24 hpi and subjected to virus titration to evaluate the magnitude of SARS-CoV-2 infection as described above.

\section{Virus binding and internalization assay}

A proteinase $\mathrm{K}$ infection assay was conducted to assess the efficiency of proteinase $\mathrm{K}$ treatment as described previously [26]. Vero E6 cells were grown in 6-well culture plates and incubated with SARS-CoV-2 at an MOI of 1 at $4^{\circ} \mathrm{C}$ for $1 \mathrm{~h}$. The cells were washed with PBS and treated with proteinase $\mathrm{K}(0.5-1 \mathrm{mg} / \mathrm{ml})$ at $4^{\circ} \mathrm{C}$ for $45 \mathrm{~min}$. After treatment, the supernatant was removed, and total RNA was extracted from the cell lysates using TRIzol Reagent (Invitrogen) and then treated with DNase I (TaKaRa, Otsu, Japan) according to the manufacturer's instructions. The concentration of the extracted RNA was measured using a NanoVue spectrophotometer (GE Healthcare). Quantitative real-time RT-PCR was performed using a One Step SYBR PrimeScript RTPCR Kit (TaKaRa) and specific primers (forward primer, 5'-GACCCCAAAATCAGCGAAAT-3'; reverse primer, 5'-TCTGGTTACTGCCAGTTGAATCTG-3'). A primer set targeting monkey $\beta$-actin included the forward primer 5'-GGTCTTCTGTCACCTGATTT- 3 ' and the reverse primer 5'- CATCCACCTCCACTTCTCTAAC- $3^{\prime}$. The reaction was performed using a Thermal Cycler Dice Real Time System (TaKaRa) according to the manufacturer's protocol. The amount of viral RNA was determined by real-time RT-PCR, using SARS-CoV-2 (P3) that was serially diluted tenfold from $10^{6}$ to $10^{1} \mathrm{TCID}_{50}$, and a standard curve was generated for each PCR plate. Genome copy numbers were calculated based on this standard curve and normalized to $\beta$-actin gene copy numbers comparing cycle threshold values determined in parallel.

Binding and internalization assays were performed as described previously with some modifications [24]. Vero E6 cells grown in 6-well culture plates were incubated with SARS-CoV-2 at an MOI of 1 at $4^{\circ} \mathrm{C}$ for $1 \mathrm{~h}$. After removing unbound viruses by washing with PBS, the cells were incubated at either $4^{\circ} \mathrm{C}$ (allowing virus binding only) or $37^{\circ} \mathrm{C}$ (permitting both virus binding and internalization) in the presence of trypsin for $1 \mathrm{~h}$ : in the latter case, the cells were further treated with proteinase $\mathrm{K}(0.5 \mathrm{mg} / \mathrm{ml})$ at $37^{\circ} \mathrm{C}$ for $45 \mathrm{~min}$ to remove bound but uninternalized virus particles. The SARS-CoV-2-infected cells were then serially diluted in DMEM and inoculated onto fresh Vero E6 cell monolayers in 96-well tissue culture plates. At $24 \mathrm{~h}$ post-incubation, bound or internalized viruses were titrated as described above, and the $\mathrm{TCID}_{50}$ was determined.

\section{Quantitative real-time RT-PCR (qRT-PCR)}

Vero E6 cells in 96-well culture plates were treated with DMEM containing $1 \mu \mathrm{M} \mathrm{BafA} 1$ at $37^{\circ} \mathrm{C}$ for $30 \mathrm{~min}$ and then chilled at $4^{\circ} \mathrm{C}$ for $10 \mathrm{~min}$ as described previously [13]. The cells were infected with SARS-CoV-2 at an MOI of 1 at $4^{\circ} \mathrm{C}$. After a 30-min adsorption period, the virus was removed, and infected cells were treated with each protease in culture medium supplemented with BafA1 at room temperature for $5 \mathrm{~min}$. After the protease was removed, the cells were maintained in the presence of BafA 1 at $37^{\circ} \mathrm{C}$ for $6 \mathrm{~h}$. Viral RNA was extracted from the cell lysates using the TRIzol Reagent and prepared as described above. The RNA concentration was measured, and SARS-CoV-2 N-gene-based quantitative real-time RT-PCR was performed using a One Step PrimeScript RT-PCR Kit (TaKaRa) and a specific primer set (forward primer, 5'-GACCCCAAAATCAGCGAAAT-3'; reverse primer, 5'-TCTGGTTACTGCCAGTTGAATCTG $\left.-3^{\prime}\right)$ and the probe 5'-FAM-ACCCCGCATTACGTTTGG TGGACC-BHQ1-3'. The reaction was performed using a Thermal Cycler Dice Real Time System (TaKaRa) according to the manufacturer's protocol under the following conditions: 1 cycle of $45^{\circ} \mathrm{C}$ for $30 \mathrm{~min}, 1$ cycle of $95^{\circ} \mathrm{C}$ for 10 min, and 40 cycles of $95^{\circ} \mathrm{C}$ for $15 \mathrm{~s}$ and $60^{\circ} \mathrm{C}$ for $1 \mathrm{~min}$. The results were analyzed using the system software as described previously $[22,27]$. To measure the amounts of virus that 
A

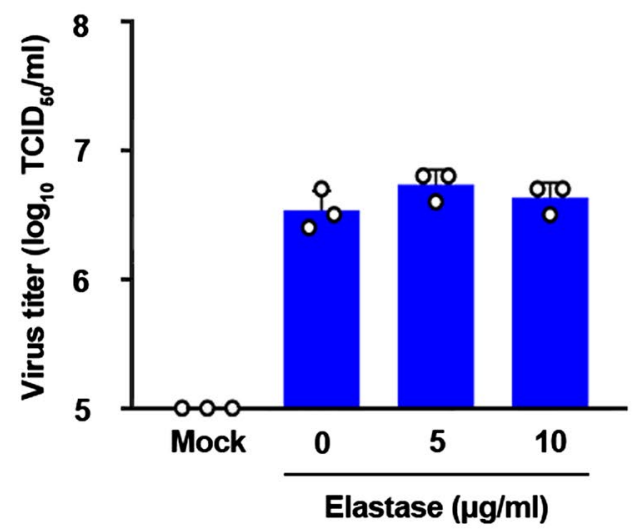

C

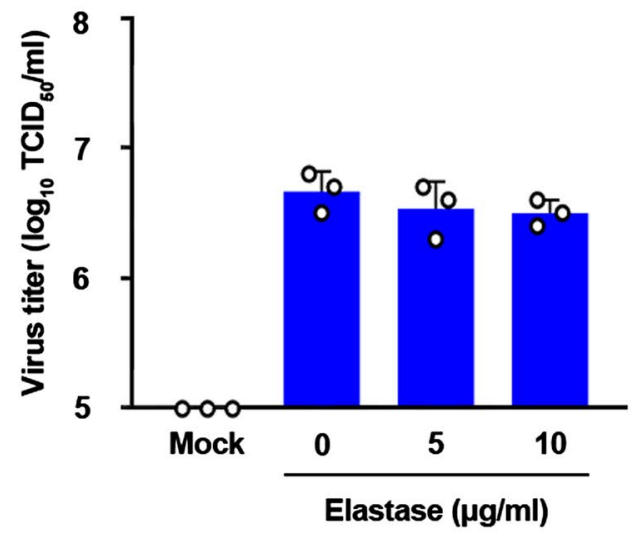

E

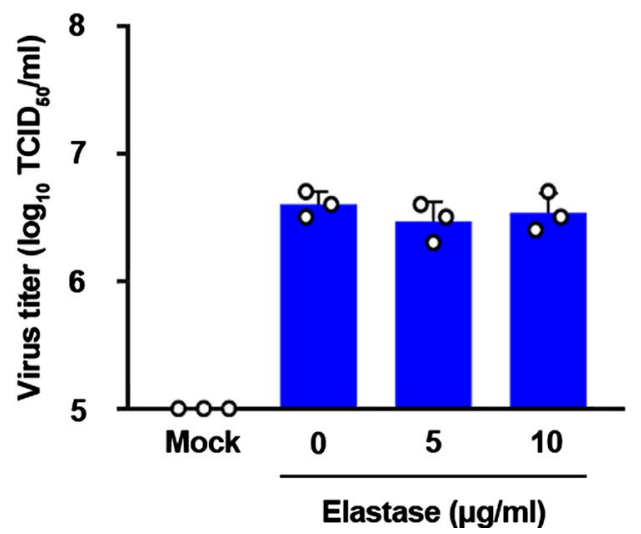

Elastase $(\mu \mathrm{g} / \mathrm{ml})$

B

Mock
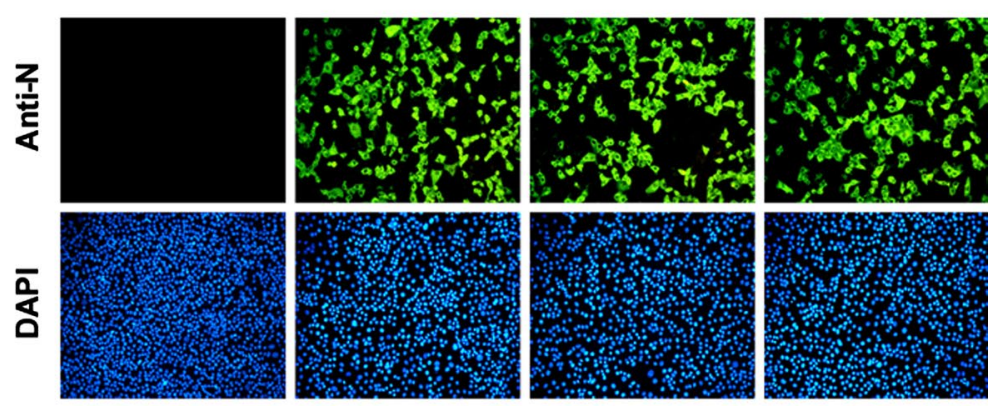

D
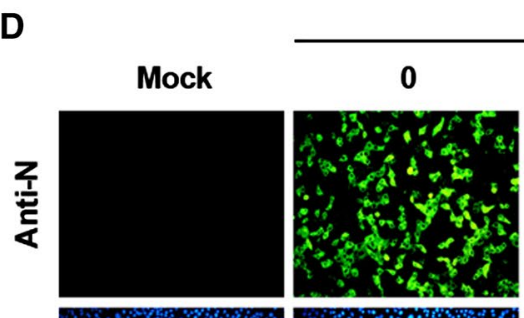

Elastase $(\mu \mathrm{g} / \mathrm{ml})$
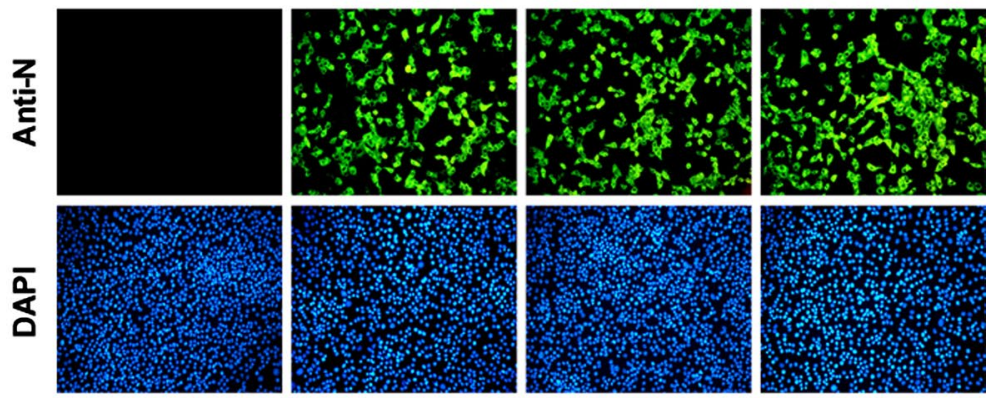

$\mathbf{F}$

Elastase $(\mu \mathrm{g} / \mathrm{ml})$
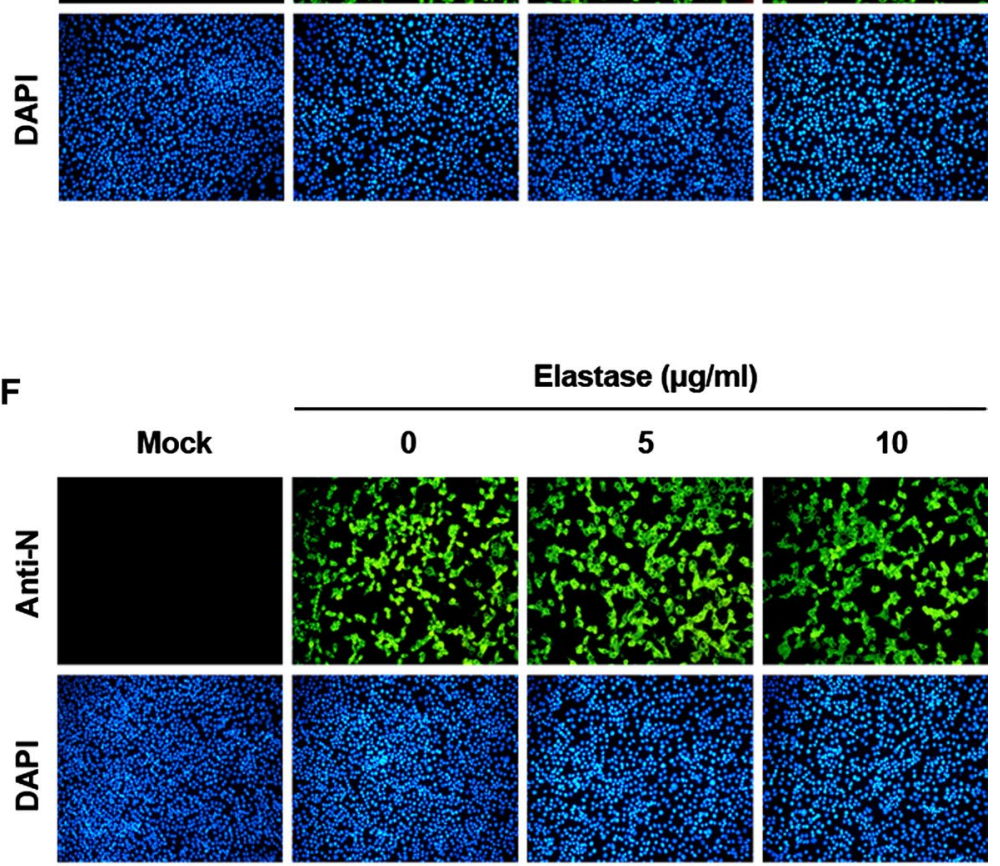

entered into cells, we infected cells with SARS-CoV-2 (P3) diluted tenfold stepwise from $10^{6}$ to $10^{1} \mathrm{TCID}_{50}$. The viral RNA was quantified by qRT-PCR, and a standard curve was generated for each PCR plate. The virus concentration (genomic copies/ml) in each sample was calculated based on this standard curve.

\section{Nucleotide sequence analysis}

The complete genome sequences of SARS-CoV-2-P2 and cell-adapted -P3, -P10, -P20, -P30, -P40, and -P50 strains were determined by the traditional Sanger method as described previously with some modifications [19, 22]. 
4Fig. 3 Effect of elastase on SARS-CoV-2 infection. (A and B) Vero E6 cells were preincubated with elastase for $1 \mathrm{~h}$ before infection and then mock infected or infected with SARS-CoV-2 (P3) at an MOI of 1 for $1 \mathrm{~h}$ without elastase addition. The virus-infected cells were then maintained in the absence of elastase. (C and D) Vero E6 cells were mock infected or infected with SARS-CoV-2 (P3) at an MOI of 1 for $1 \mathrm{~h}$ in the presence of elastase. The virus-infected cells were then maintained in the absence of elastase. (E and F) Vero E6 cells were mock infected or infected with SARS-CoV-2 (P3) at an MOI of 1 for $1 \mathrm{~h}$ without elastase addition. The virus-infected cells were then maintained in the presence of elastase. The virus supernatants were collected at $24 \mathrm{hpi}$, and viral titers were determined (A, C, and E). For immunostaining, infected cells were fixed at $24 \mathrm{hpi}$ and incubated with an MAb against the SARS-CoV-2 N protein, followed by incubation with Alexa green-conjugated goat anti-mouse secondary antibody (top panels). The cells were then counterstained with DAPI (bottom panels) and examined under a fluorescence microscope at $200 \times$ magnification (B, D, and F). The values shown are the mean of three independent experiments, and error bars show the SDM.

Viral RNA was extracted from each virus stock serially passaged in Vero E6 cells and was used as a template to amplify 11 overlapping cDNA fragments encompassing the entire genome of each virus strain using RT-PCR. The individual amplicons were gel-purified, cloned into pGEMT Easy Vector (Promega, Madison, WI), and sequenced in both directions using two commercial vector-specific T7 and SP6 primers and viral-gene-specific primers. The 5' and $3^{\prime}$ ends of the genomes of each strain were determined by rapid amplification of cDNA ends (RACE) as described previously [28]. The complete genomic nucleotide sequence of the virus from each passage was deposited in the GenBank database under the accession numbers MZ930250 to MZ930252, MZ930392 to MZ930396, and MZ995184 to MZ995188.

\section{Statistical analysis}

All values are expressed as the mean \pm standard deviation of the mean difference (SDM). Statistical analysis was conducted using the GraphPad Prism 7 software package (GraphPad Software, San Diego, CA). $P$-values $\leq 0.05$ were considered to be statistically significant.

\section{Results}

\section{Effect of trypsin in SARS-CoV-2 infection}

To investigate the effect of trypsin treatment on viral replication, Vero E6 cells were incubated for $1 \mathrm{~h}$ with trypsin at different concentrations $(0,1.25,2.5,5$, and $10 \mu \mathrm{g} / \mathrm{ml})$ and infected with SARS-CoV-2 (P3) at an MOI of 1 for $1 \mathrm{~h}$ or mock-infected. The infected cells were washed once with PBS and cultivated in cell growth medium without trypsin. According to the MTT cell viability assay, none of the trypsin dosages examined in this study resulted in a measurable level of cell death (Table 1). We initially quantified virus production by virus titration at $24 \mathrm{hpi}$. The virus yields remained unchanged, with a mean titer range of $10^{6.53}-10^{6.73}$ $\mathrm{TCID}_{50} / \mathrm{ml}$ regardless of the presence or absence of trypsin before infection (Fig. 1A). SARS-CoV-2 replication was also measured by monitoring the intensity of the cytopathic effect (CPE) and was confirmed by IFA using an anti-N-protein $\mathrm{MAb}$ at 24 hpi. As shown in Fig. 1B, treating cells with trypsin before virus infection had no effect on SARS-CoV-2 infectivity at any of the concentrations tested compared to the untreated control. Furthermore, SARS-CoV-2 propagation in cell culture was unaffected by adding exogenous trypsin during the 1-h inoculation period (Fig. 1C and D). These results revealed that trypsin treatment before or during infection did not influence SARS-CoV-2 replication.

Next, we investigated whether SARS-CoV-2 infectivity is enhanced by supplementing the medium with trypsin after SARS-CoV-2 infection. Vero E6 cells were infected with SARS-CoV-2 at an MOI of 1 for $1 \mathrm{~h}$ without trypsin and then propagated in FBS-free medium with trypsin at different concentrations $(0,1.25,2.5,5$, and $10 \mu \mathrm{g} / \mathrm{ml})$. Unless otherwise specified, trypsin was present throughout the infection period. When exogenous trypsin was added after inoculation, virus titers were considerably higher than without trypsin (Fig. 1E). The highest viral titer $\left(10^{7.52} \mathrm{TCID}_{50} /\right.$ $\mathrm{ml}$ ) was achieved in the presence of $5 \mu \mathrm{g}$ of trypsin per ml, which was 1 log higher than the control mean titer $\left(10^{6.67}\right.$ $\left.\mathrm{TCID}_{50} / \mathrm{ml}\right)$. CPE observations and IFA analysis revealed that the virus infectivity increased when the virus-infected cells were cultivated in the presence of trypsin (Fig. 1F). In another experiment, Vero E6 cells were inoculated with tenfold serially diluted SARS-CoV-2 and maintained in the presence or absence of trypsin $(5 \mu \mathrm{g} / \mathrm{ml})$, and IFA was used to visualize infected cells (Fig. 2). The results revealed that when Vero E6 cells were propagated in the presence of trypsin, the number of infected cells was more than tenfold higher than in the cultures without trypsin. The virus growth medium (high-glucose DMEM supplemented with penicillin-streptomycin and $5 \mu \mathrm{g}$ of trypsin per $\mathrm{ml}$ ) was then used in all subsequent experiments unless otherwise indicated. We also tested the effect of another protease, elastase, on SARS-CoV-2 under the same experimental conditions. However, no apparent effect of elastase on SARS-CoV-2 replication was detected in cell culture when cells were treated with elastase at non-cytotoxic concentrations $(5-10 \mu \mathrm{g} / \mathrm{ml}$; Table 1) before, during, or after infection (Fig. 3).

To establish the point at which trypsin affects SARSCoV-2 infection, we added trypsin to Vero E6 cells at different time points after infection. At $24 \mathrm{hpi}$, the extent of viral replication was assessed directly by virus titration. As shown in Fig. 4, the addition of trypsin at up to 2 hpi (i.e., 3 $\mathrm{h}$ after inoculation) resulted in a considerable enhancement 


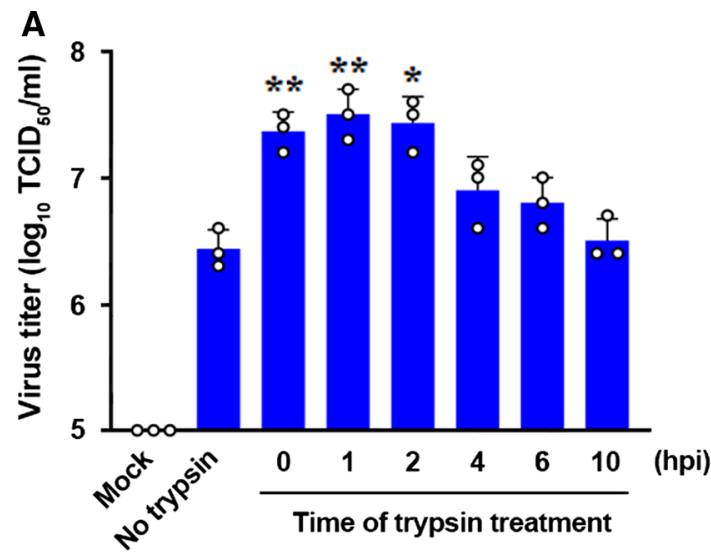

Fig. 4 Effect of proteases on SARS-CoV-2 propagation at early time points postinfection. Vero E6 cells were mock infected or infected with SARS-CoV-2 (P3) at an MOI of 1. At the indicated time points postinfection, trypsin (A) or elastase (B) was added to achieve a final concentration of 5 or $10 \mu \mathrm{g} / \mathrm{ml}$, respectively. At $12 \mathrm{hpi}$, the culture

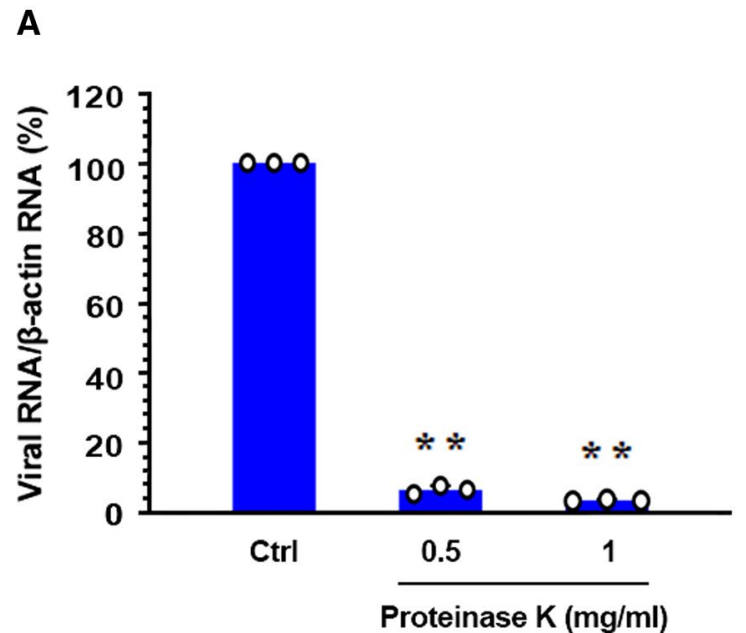

Fig. 5 Effect of trypsin on SARS-CoV-2 entry. (A) Vero E6 cells were incubated with SARS-CoV-2 at an MOI of 1 at $4^{\circ} \mathrm{C}$ for $1 \mathrm{~h}$, after which the unbound virus was removed and the cells were treated with proteinase $\mathrm{K}(0.5-1 \mathrm{mg} / \mathrm{ml})$ at $4^{\circ} \mathrm{C}$ for $45 \mathrm{~min}$. The cells were collected in TRIzol for RNA isolation and determination of the SARS-CoV-2 RNA copy number. Results are shown as a percentage of SARS-CoV-2 RNA copy number compared with controls (ctrl) in which PBS was substituted for proteinase K. (B) Vero E6 cells were infected with SARS-CoV-2 at an MOI of 1 at $4^{\circ} \mathrm{C}$ for $1 \mathrm{~h}$ and washed with cold PBS. The infected cells were then incubated in the pres-

of infectivity. However, when trypsin was introduced at or after $4 \mathrm{hpi}$, little or no increase in virus propagation was observed. These findings established that trypsin must be present during the early stages of viral infection in order to effectively enhance SARS-CoV-2 infection. Taken together, our results suggest that trypsin participates in the entry pathway of SARS-CoV-2.

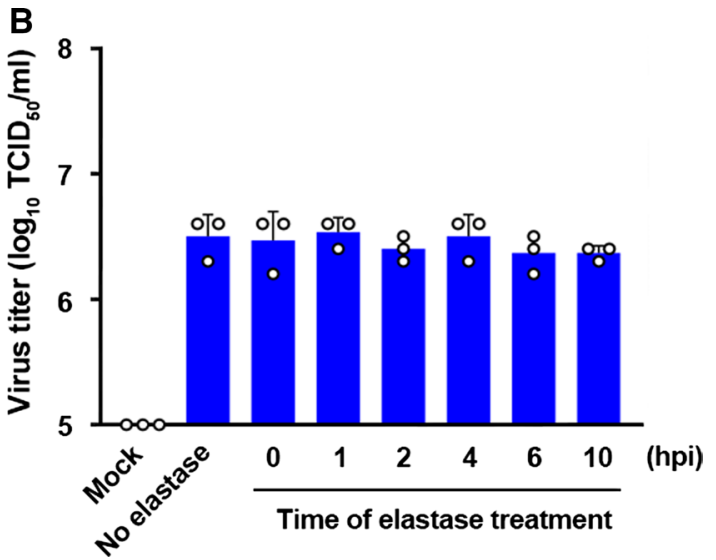

supernatant was collected, and virus production was quantified by virus titration. Results are presented as the mean of three independent experiments, and error bars show the SDM. *, $P<0.05$; **, $P<$ 0.001

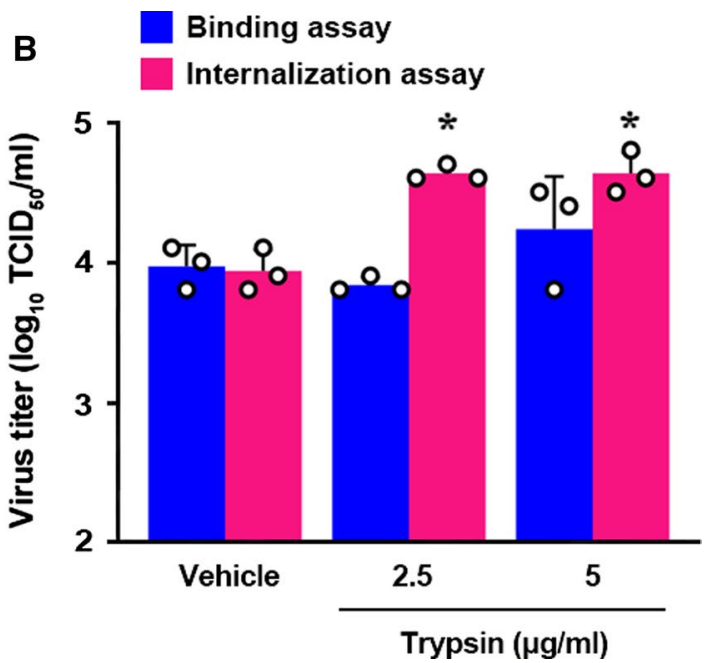

ence or absence of trypsin $(5 \mu \mathrm{g} / \mathrm{ml})$, either at $4^{\circ} \mathrm{C}$ (binding; blue bars) or $37^{\circ} \mathrm{C}$ (internalization; red bars), for an additional $1 \mathrm{~h}$. The virus-infected cells that were incubated at $37^{\circ} \mathrm{C}$ were then treated with proteinase $\mathrm{K}(0.5 \mathrm{mg} / \mathrm{ml})$ at $37^{\circ} \mathrm{C}$ for $45 \mathrm{~min}$. The infected cells were then serially diluted and plated onto fresh Vero E6 cells. At $24 \mathrm{~h}$ post-incubation, bound or internalized viruses were titrated. Data are expressed as the mean of three independent experiments performed in triplicate, and error bars represent the SDM. *, $P<0.05$; **, $P<$ 0.001

\section{Effect of trypsin treatment on virus internalization}

We next investigated whether trypsin facilitates the entry of SARS-CoV-2 in cultured cells. To establish the parameters for the viral internalization assay used to monitor SARS$\mathrm{CoV}-2$ entry, we used a proteinase $\mathrm{K}$ infection assay to determine the rate of virus attachment and penetration by 
quantifying bound and internalized virus particles, respectively. To determine the effectiveness of proteinase $\mathrm{K}$ treatment in removing bound viruses, Vero E6 cells were infected with SARS-CoV-2 for $1 \mathrm{~h}$ at $4^{\circ} \mathrm{C}$ and then treated with proteinase $\mathrm{K}$ at the specified doses for $45 \mathrm{~min}$ at $4^{\circ} \mathrm{C}$. The quantity of virus bound to the cells was measured using qRT-PCR to determine the SARS-CoV-2 genome copy number. As shown in Fig. 5A, proteinase $\mathrm{K}$ treatment had a substantial effect on the number of virions bound at the cell surface, suggesting that virus attached to the cells is efficiently removed by proteinase $\mathrm{K}$ treatment.

We then examined the two phases of viral entry - attachment and penetration - in the presence of trypsin using virus binding and internalization assays. Vero E6 cells were inoculated with SARS-CoV-2 at $4^{\circ} \mathrm{C}$ for $1 \mathrm{~h}$ to enable only virus attachment and then maintained at $4^{\circ}$ or $37^{\circ} \mathrm{C}$ in the presence of trypsin to limit or permit virus internalization, respectively, after which proteinase $\mathrm{K}$ was used to remove any remaining virus particles from the cell surface. Serial dilutions of infected cells were performed on fresh Vero E6 cell monolayers, and the viral titers were determined (Fig. 5B). Regardless of the presence or absence of trypsin, the viral titers were equivalent among cells treated at $4^{\circ} \mathrm{C}$ to allow virus binding but inhibit penetration, However, virus production was considerably enhanced by trypsin treatment in cells maintained at $37^{\circ} \mathrm{C}$ to allow virus internalization to progress when compared to the vehicle control without trypsin under the same conditions. These findings suggest that trypsin treatment accelerates internalization of SARS-CoV-2.

\section{SARS-CoV-2 entry at the cell surface facilitated by trypsin}

To test whether SARS-CoV-2 enters cells by a pH-dependent endosomal pathway, we first evaluated the effect of BafA1, a lysosomotropic agent, on SARS-CoV-2 replication by virological analysis. Vero E6 cells were treated with BafA1 at concentrations of 0.1 and $0.5 \mu \mathrm{M}$ or $\mathrm{DMSO}(0.5 \%)$ as a vehicle control before, during, or after infection. An MTT assay did not reveal any cellular cytotoxicity in the drug-treated cells at the concentrations used in the study (Table 1). Virus production was measured by virus titration and IFA using an anti-N protein MAb at 24 hpi (Fig. 6). Treating cells with BafA1 before or during infection significantly suppressed infection (Fig. 6A and C) and reduced the level of SARS-CoV-2 N expression (Fig. 6B and D) in a dosedependent manner. By contrast, virus propagation remained unchanged when BafA1 was added after infection (Fig. 6E and F). These results suggest that SARS-CoV-2 entry occurs through an endosomal pathway.
We then investigated the effectiveness of trypsin in facilitating SARS-CoV-2 entry directly at the cell surface. Vero E6 cells treated with BafA1 at a concentration of $0.5 \mu \mathrm{M}$ were inoculated with SARS-CoV-2 at an MOI of 1 and kept at $4^{\circ} \mathrm{C}$ for $30 \mathrm{~min}$ to block the virus from entering cells. The cells were then treated with different proteases at room temperature for $5 \mathrm{~min}$ and maintained at $37^{\circ} \mathrm{C}$ for $6 \mathrm{~h}$, and the amount of virus that was internalized was measured by qRT-PCR (Fig. 7). Trypsin greatly facilitated SARSCoV-2 entry, whereas elastase did not influence viral entry (Fig. 7A). Trypsin treatment of cells prior to viral infection had no influence on SARS-CoV-2 internalization (Fig. 7B), showing that the effect of trypsin on the cells themselves is irrelevant for infection. These results imply that SARSCoV-2 entry occurs via non-endosomal, direct fusion with the plasma membrane in the presence of trypsin, which cleaves the fusion-inducing $\mathrm{S}$ protein.

Treatment with high concentrations $(10-75 \mu \mathrm{g} / \mathrm{ml})$ of trypsin resulted in an enhancement of virus entry and replication when compared with normal infection without trypsin (Fig. 7A; compare bars 6-8 with bar 1 from left). The replication kinetics of SARS-CoV-2 were then compared in cells treated with BafA1 $(0.5 \mu \mathrm{M})$ and a high concentration (75 $\mu \mathrm{g} / \mathrm{ml}$ ) of trypsin to those in virus-infected cells maintained in the absence of BafA1 and trypsin. At each point during the early stage of infection, trypsin-treated cells produced substantially more virus (Fig. 7C).

\section{Phenotypic and genotypic characterization of SARS-CoV-2 serially passaged in the presence or absence of trypsin}

We serially propagated viruses in vitro for up to 50 passages in the presence or absence of trypsin and generated virus stocks every 10 passages, labeled P10, P20, P30, P40, and P50. Like the parental virus (P3), all SARS-CoV-2 strains cultured in the absence of trypsin produced CPE typical of viral infection, including cell rounding, clumping together in clusters, and detachment, in infected Vero E6 cells (Fig. 8, left panels). However, trypsin-adapted strains induced different patterns of CPE that included cell fusion and multinucleated cells, or syncytia (Fig. 8, right panels). Vacuoles and syncytia were larger and more predominant in cells infected with SARS-CoV-2 strains that were consecutively passaged in the presence of trypsin. As a consequence, the size of syncytia increased progressively with the serial passage number, and the high-passage P50 virus generated prevalent syncytia with many more nuclei than the low-passage $\mathrm{P} 10$ virus in the presence of trypsin (Fig. 8; compare panel $n$ with panel j).

To examine the phenotypic characteristics of serially passaged SARS-CoV-2 strains in vitro, we evaluated the one-step growth rates of representative $\mathrm{P} 3$ and P10 strains cultured with or without trypsin (Fig. 9). Without trypsin 


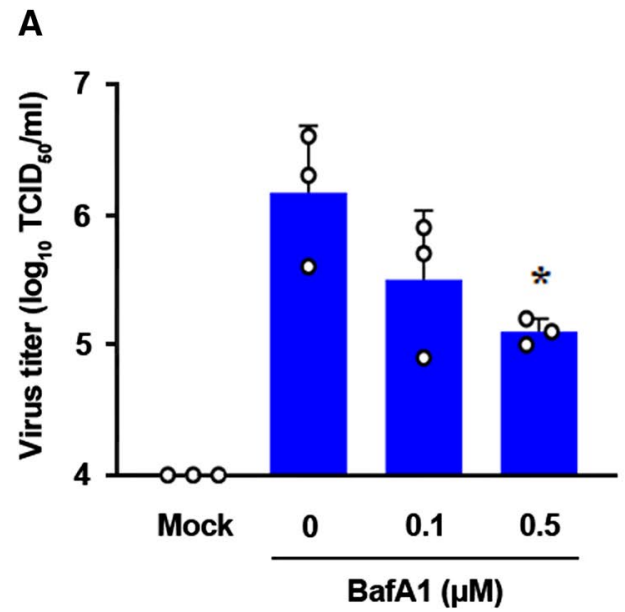

B

B Mock

BafA1 ( $\mu M)$
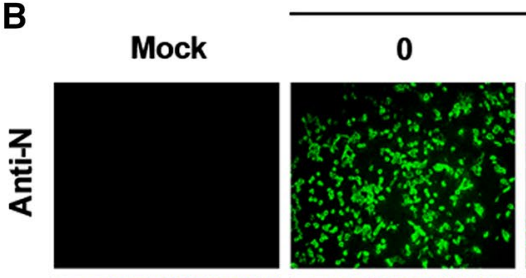

0.1

0.5
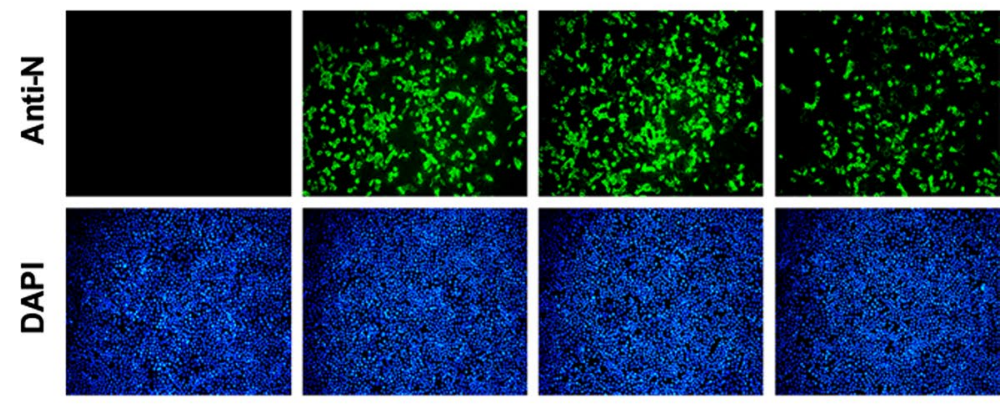

C

D
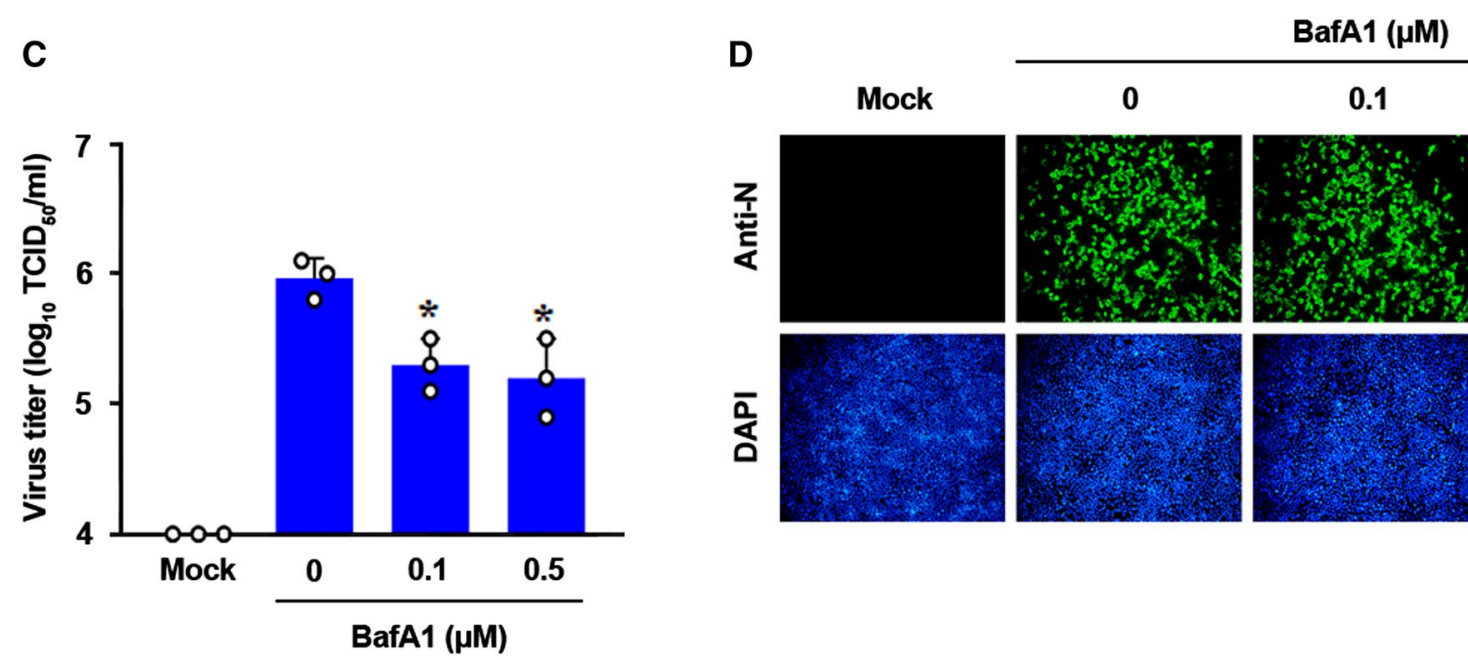

0.1
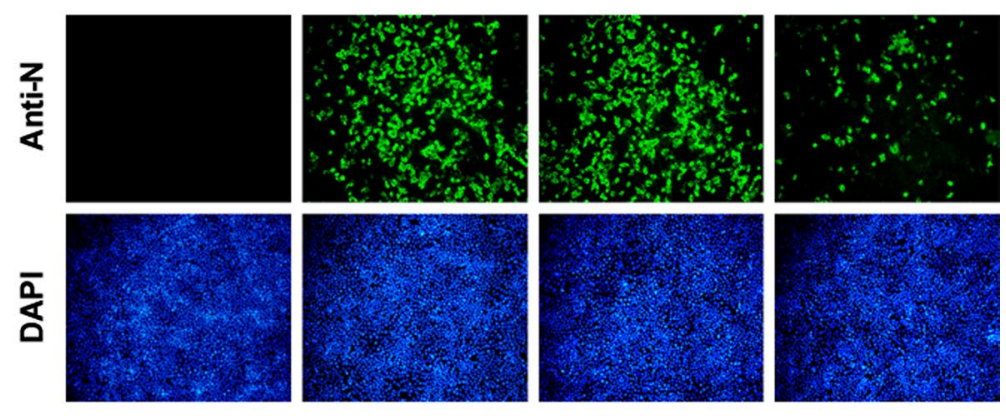

E

$\mathbf{F}$
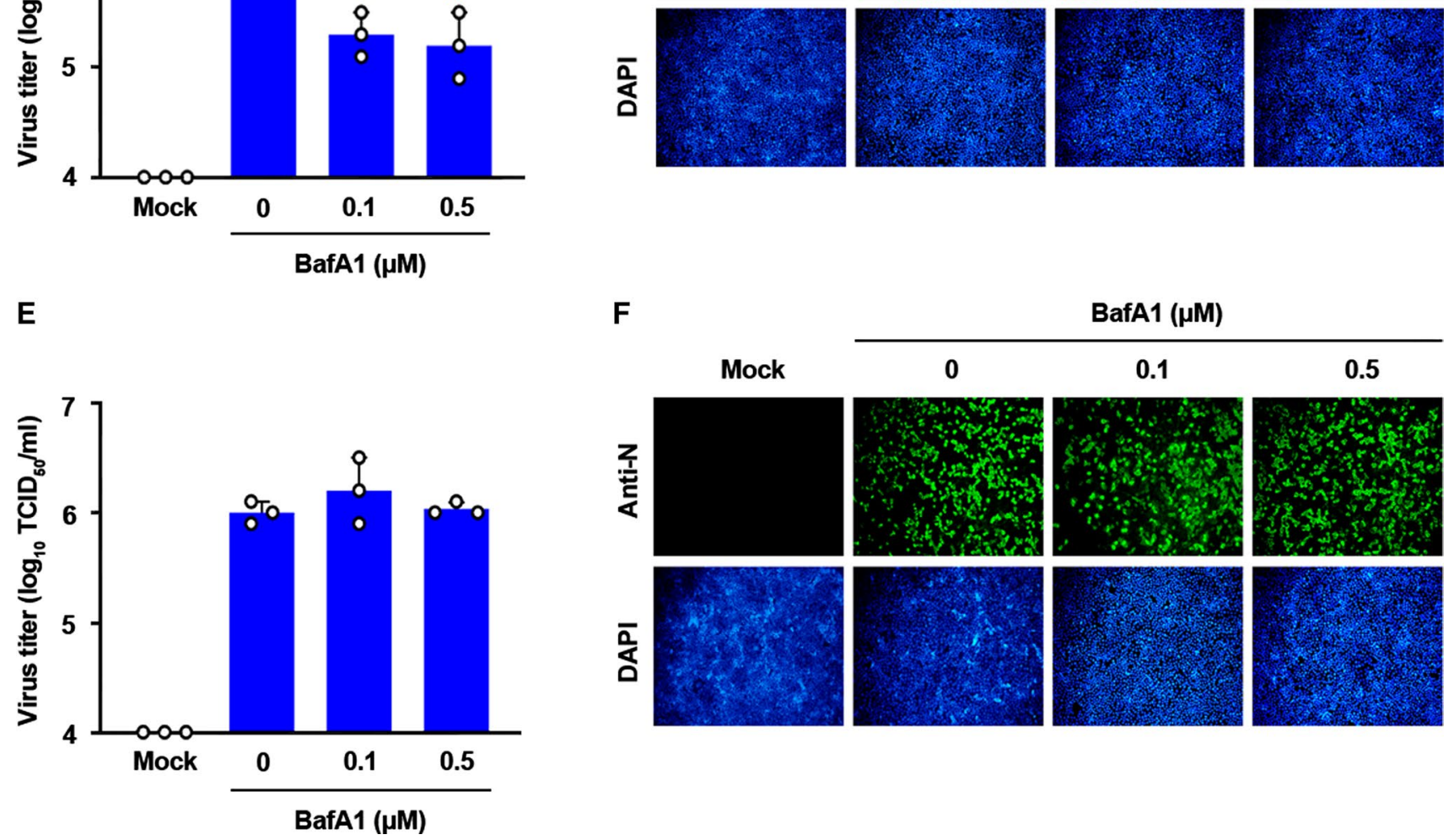

Mock
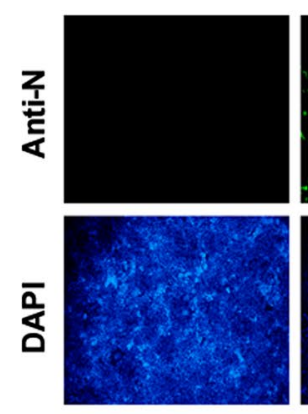
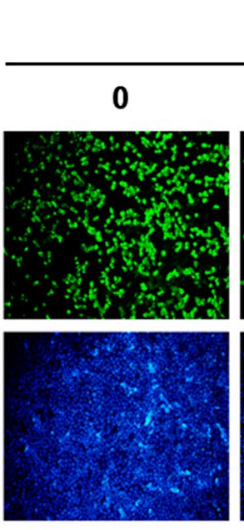

BafA1 ( $\mu$ M)

$0.1 \quad 0.5$
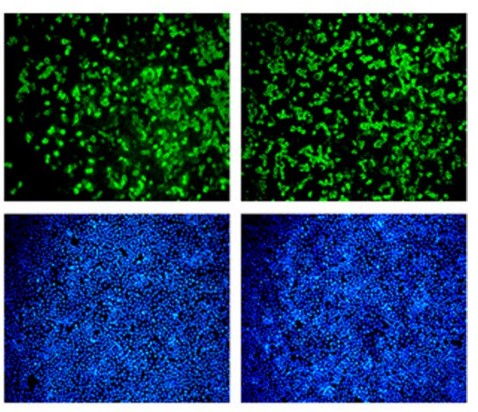

treatment, the parental P3 virus had the fastest growth rate, showing a peak titer of $10^{5.57} \mathrm{TCID}_{50} / \mathrm{ml}$ at $24 \mathrm{hpi}$, after which its growth declined (Fig. 9A). By contrast, the growth rate of the $\mathrm{P} 3$ virus increased significantly in the presence of trypsin. At $12 \mathrm{hpi}$, the titer of the P3 virus increase rapidly in the presence of trypsin, continuing until $48 \mathrm{hpi}$, ranging from $10^{6.33}$ to $10^{7} \mathrm{TCID}_{50} / \mathrm{ml}$. In contrast, cell-adapted virus serially passaged under trypsin-free conditions produced growth curves and virus titers that were similar to those of the P3 virus, with a maximum at 24 hpi (Fig. 9B). Despite the comparable growth curves of the $\mathrm{P} 3$ and $\mathrm{P} 10$ strains, the trypsin-adapted virus grew faster and produced higher titers 
4Fig. 6 Effect of BafA1 on SARS-CoV-2 infection. (A and B) Vero E6 cells were preincubated with BafA1 for $1 \mathrm{~h}$ before infection and then mock infected or infected with SARS-CoV-2 (P3) at an MOI of 1 for $1 \mathrm{~h}$ without BafA1 addition. The virus-infected cells were then maintained in the absence of BafA1. (C and D) Vero E6 cells were mock infected or infected with SARS-CoV-2 (P3) at an MOI of 1 for $1 \mathrm{~h} \mathrm{in}$ the presence of BafA1. The virus-infected cells were then maintained in the absence of BafA1. (E and F) Vero E6 cells were mock infected or infected with SARS-CoV-2 (P3) at an MOI of 1 for $1 \mathrm{~h}$ without BafA1 addition. The virus-infected cells were then maintained in the presence of BafA1. The virus supernatants were collected at $24 \mathrm{hpi}$, and viral titers were determined (A, C, and E). For immunostaining, infected cells were fixed at $24 \mathrm{hpi}$ and incubated with an MAb against the SARS-CoV-2 $\mathrm{N}$ protein, followed by incubation with Alexa green-conjugated goat anti-mouse secondary antibody (top panels). The cells were then counterstained with DAPI (bottom panels) and examined under a fluorescence microscope at $200 \times$ magnification $(\mathrm{B}, \mathrm{D}$, and $\mathrm{F})$. The values shown are the mean of three independent experiments, and error bars show the SDM. *, $P=0.001$ to 0.05

as the passage number increased. In particular, cells infected with the trypsin-adapted P10 virus reached virus titers of $10^{7.93} \mathrm{TCID}_{50} / \mathrm{ml}$ at $12 \mathrm{hpi}$, which continued to increase up to $48 \mathrm{hpi}$, reaching a maximum that was 100 -fold higher than that of the parental or passaged strain without trypsin addition. Compared to the P10 virus cultured in the presence of trypsin, the growth patterns were comparable among further trypsin-adapted P20-P50 strains passaged in the presence of trypsin (data not shown). These results demonstrate that trypsin is able to promote SARS-CoV-2 infection by facilitating cell-to-cell fusion.

To evaluate the genomic alterations that may have occurred during in vitro serial passage in Vero E6 cells in the presence or absence of trypsin, we determined the full-length nucleotide sequences of the parental P2 and its derived passages, P3-P50, using Sanger sequencing and RACE. The sequence data did not show any mutations in the $\mathrm{P} 3$ virus propagated in the presence $(+)$ or absence $(-)$ of trypsin compared with the original KCDC03 P2 strain. Although the $5^{\prime}$ and $3^{\prime}$ untranslated regions (UTRs) remained unchanged during in vitro serial passage in Vero E6 cells, mutations occurred in the protein-coding regions and the number of mutations increased gradually over time. At the nucleotide level, the genome sequences of P3(+) and P3(-) were nearly identical (99.94-99.99\%) to that of the corresponding celladapted strain. In comparison to the parental P3(+) or P3(-) strain, the number of nucleotide/amino acid substitutions increased in direct proportion to the number of in vitro passages (Table 2).

Interestingly, the number and location of the amino acid (aa) changes differed between the cell-culture-passaged strains in the presence or absence of trypsin (Fig. 10). The 50th-passage strain without trypsin addition contained nine aa mutations, including three aa deletions (DELs), whereas the $\mathrm{P} 50(+)$ virus had 23 aa variations, including 13 aa DELs. The nine aa mutations in the P50(-) virus were distributed in open reading frames (ORFs) 1a, 2, 4, and 9, encoding nsp1, S, E, and N, respectively. Among these, five aa changes were in the S protein of P50(-). Notably, one aa mutation (R685S) was found in the S1/S2 furin cleavage site (FCS), which contains multiple basic amino acids $\left({ }^{681}\right.$ PRRAR $^{685}$ ) (Table 3), which occurred in P10(-). One(M) and two- (QA) amino-acid DELs emerged independently in $\mathrm{nsp} 1$ and $\mathrm{N}$, respectively, during the cell culture passages in the absence of trypsin, the former in P30(-) and the latter in P10(-) (Table 3). The M-DEL at position 85 in nsp1 resulted from a three-nucleotide (AUG) DEL covering the codon for methionine (M) at positions 253-255 in ORF1a (nt 490-492 at the genome level). At positions 418 and 419 in N, the QA-DEL arose from a C-to-T substitution (C1252T) at position 1252 in ORF9 (nt 29,497 at the genome level). This change resulted in a change from CAG coding for glutamine (Q) to a TAG terminator codon at positions 1252-1254 in ORF9 (nt 29,497-29,499 at the genome level), causing a premature termination resulting in a loss of two residues ( $\mathrm{Q}$ and $\mathrm{A}$ ) from the $\mathrm{C}$-terminal end of the $\mathrm{N}$ protein.

The 23 aa variations present in the viral genome after the 50th passage in the presence of trypsin were dispersed randomly in ORFs 1a, 1b, 2, 5, 6, 7b, and 8, encoding nsp6, nsp13, S, M, and accessory proteins, respectively (Table 2). Although the number (five) of aa mutations in the $\mathrm{S}$ protein of P50(+) was identical to that in P50(-), their positions in the $\mathrm{P} 50(+) \mathrm{S}$ protein were completely different from those in P50(-) (Fig. 10). Intriguingly, a 13-aa DEL occurred at positions 31-43 in ORF7b of $\mathrm{P} 40(+)$ and was maintained until the 50th cell culture passage in the presence of trypsin (Table 3). The S-A-DEL resulted from a C-to-A substitution (C92A) at position 92 in ORF7b (nt 27,819 at the genome level). This mutation changed the sequence TCA, encoding serine (S), to a TAA termination codon at positions 91-93 in ORF7b (nt 27,818-27,820 at the genome level), leading to an early termination, eliminating 13 aa residues from the C-terminus of ORF7b.

\section{Discussion}

Receptor binding and subsequent proteolytic priming of the $\mathrm{S}$ protein are prerequisites for coronavirus entry into host cells. The priming event can be mediated by various host cell proteases, including trypsin, TMPRSS2, furin, and cathepsin [29]. Trypsin has been shown previously to promote the replication of porcine coronaviruses, including the emerging/re-emerging swine coronaviruses PEDV and PDCoV, and is therefore commonly used in their isolation and cultivation $[15,17,19]$. Furthermore, proteasemediated enhancement of infection is known for SARS$\mathrm{CoV}-1$, as well as viruses belonging to other families, such 


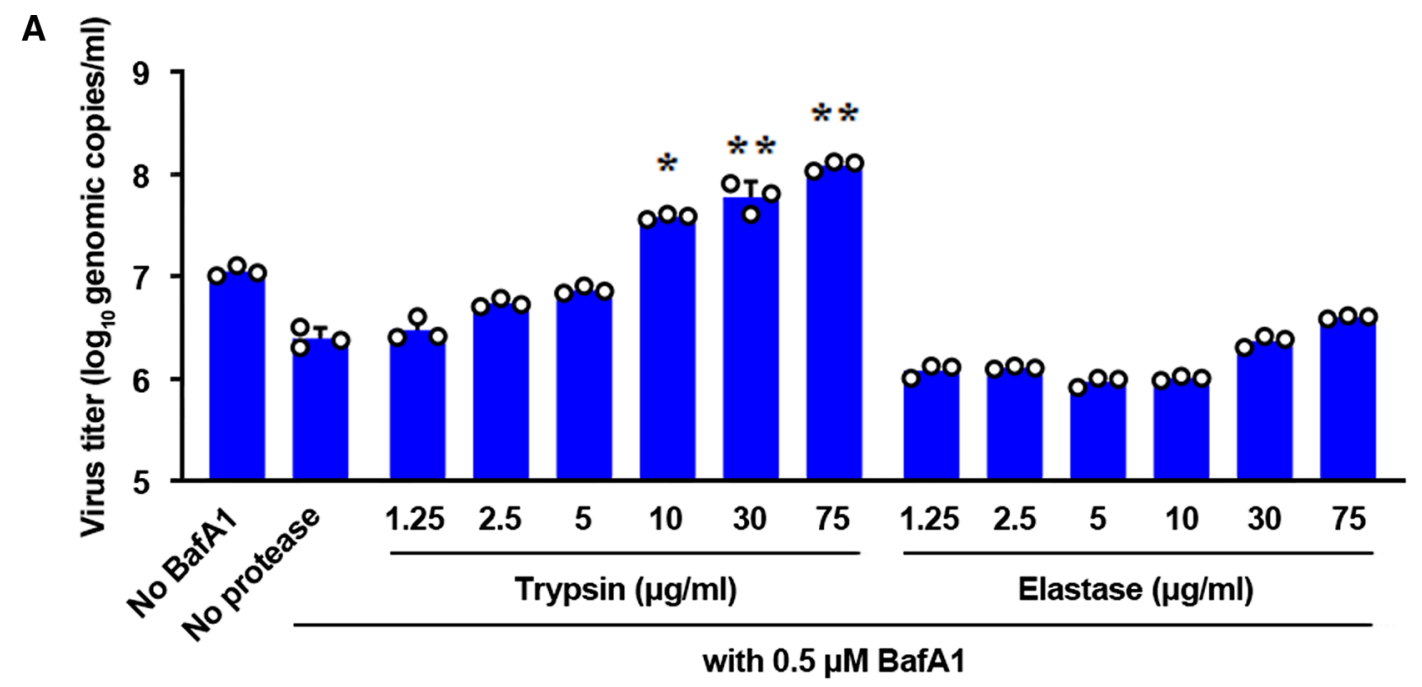

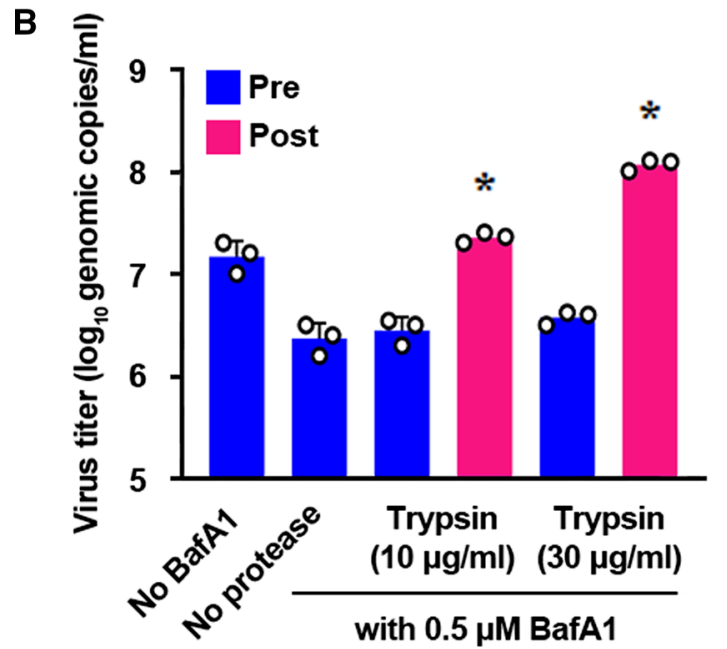

Fig. 7 Entry of SARS-CoV-2 at the cell surface facilitated by trypsin. (A) Effect of proteases on the entry of SARS-CoV-2 into Vero E6 cells treated with BafA1. Vero E6 cells cultured in 6-well plates were treated with BafA1 at a concentration of $0.5 \mu \mathrm{M}$ at $37^{\circ} \mathrm{C}$ for $30 \mathrm{~min}$, placed at $4^{\circ} \mathrm{C}$ for $30 \mathrm{~min}$, and infected with SARS-CoV-2 at an MOI of 1 for $30 \mathrm{~min}$. Then, the cells were treated with various concentrations of trypsin or elastase at room temperature for $5 \mathrm{~min}$ and maintained in the presence of BafA1 for an additional $6 \mathrm{~h}$. The amount of SARS-CoV-2 was measured quantitatively by real-time PCR. Cells not treated with BafA1 or those treated with BafA1 but not treated with trypsin or elastase were used as controls. (B) Effect of trypsin treatment before or after inoculation on SARS-CoV-2 infection in the presence of BafA1. Vero E6 cells were treated with BafA1

as influenza and parainfluenza viruses [13]. In this study, we demonstrated that trypsin treatment enhances SARSCoV-2 infection in cultured cells when it is added at early time points in infection (at least until $2 \mathrm{hpi}$ ).

The entry process of SARS-CoV-2 begins with the attachment of viral particles to the cell surface through the interaction between the viral S protein and its cellular receptor ACE2 [30]. The S protein consists of two functional

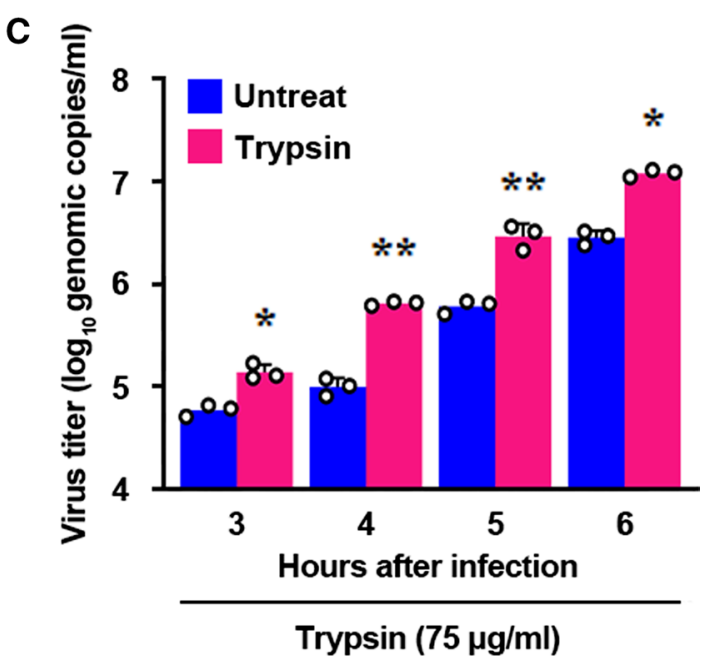

$(0.5 \mu \mathrm{M})$ at $37^{\circ} \mathrm{C}$ for $30 \mathrm{~min}$ and then treated with trypsin (10 and 30 $\mu \mathrm{g} / \mathrm{ml}$ ) at room temperature for $5 \mathrm{~min}$ before (pre) or after (post) virus inoculation. Viral infectivity was estimated quantitatively by realtime PCR. (C) SARS-CoV-2 kinetics after treatment with trypsin. Vero E6 cells were treated with BafA1, infected with SARS-CoV-2, and treated with $75 \mu \mathrm{g}$ of trypsin per $\mathrm{ml}$, as described in the legend to Fig. 7A. The production of SARS-CoV-2 was measured by realtime PCR at 3-6 h after virus inoculation. Vero E6 cells without any treatment were also infected as a control (untreated). The viral titers were expressed as genomic copies/ml. Data are expressed as the mean of three independent experiments, and error bars show the SDM. *, $P<0.05 ; * *, P<0.001$

subunits, $\mathrm{S} 1$ and $\mathrm{S} 2$; the former is responsible for ACE2 binding, and the latter is involved in the fusion of viral and cellular membranes. Following endocytic uptake of SARS-CoV-2, pH-dependent proteolytic cleavage of the $\mathrm{S}$ protein at the $\mathrm{S} 1 / \mathrm{S} 2$ junction is executed by the cellular serine protease TMPRSS2, thereby activating the entire fusion process [10]. Several other proteases, including trypsin, are known to facilitate the entry of SARS-CoV-1 at 
Fig. 8 Cytopathic changes in virus-infected cells cultured in the presence or absence of trypsin. Fifty sequential passages were performed in Vero E6 cells in the presence or absence of trypsin. Vero E6 cells were mock infected or infected with each representative cell-adapted SARS-CoV-2 strain (P3, P10, P20, P30, P40, and $\mathrm{P} 50)$ and maintained in the presence or absence of 5 $\mu \mathrm{g}$ of trypsin per ml. SARSCoV-2-specific CPE was monitored daily, and cells were photographed at 24 hpi using an inverted microscope at a magnification of $200 \times$.

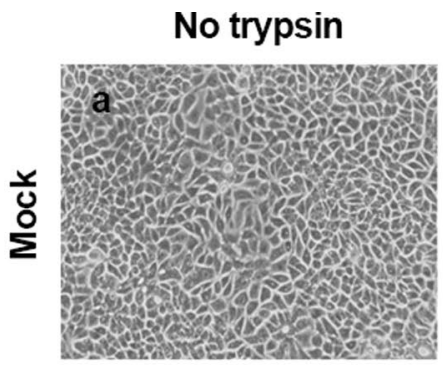

Trypsin

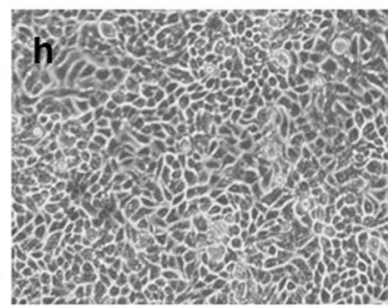

ח
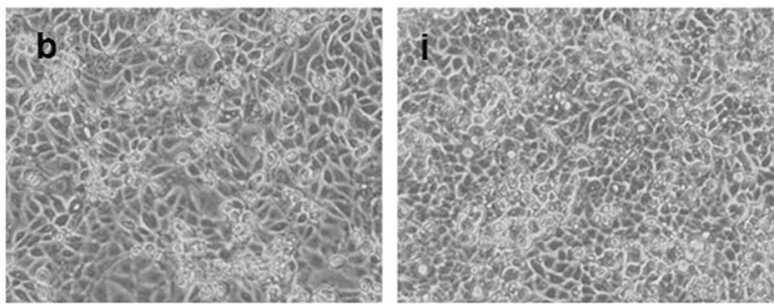

움
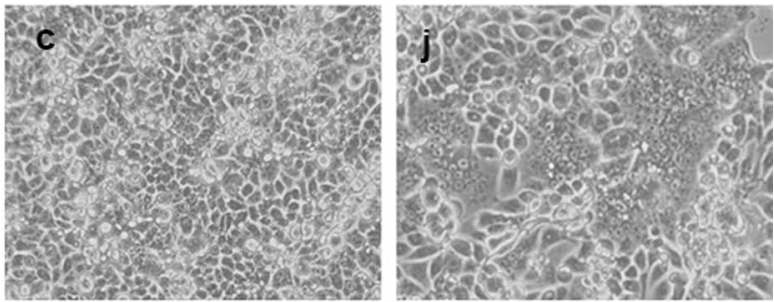

ণั

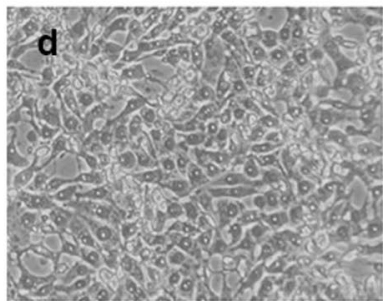

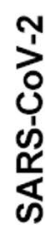

吕
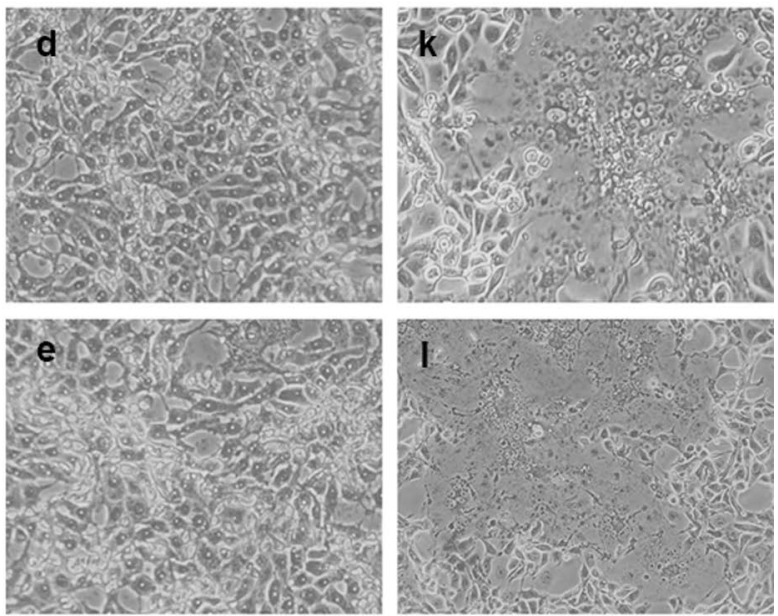

움
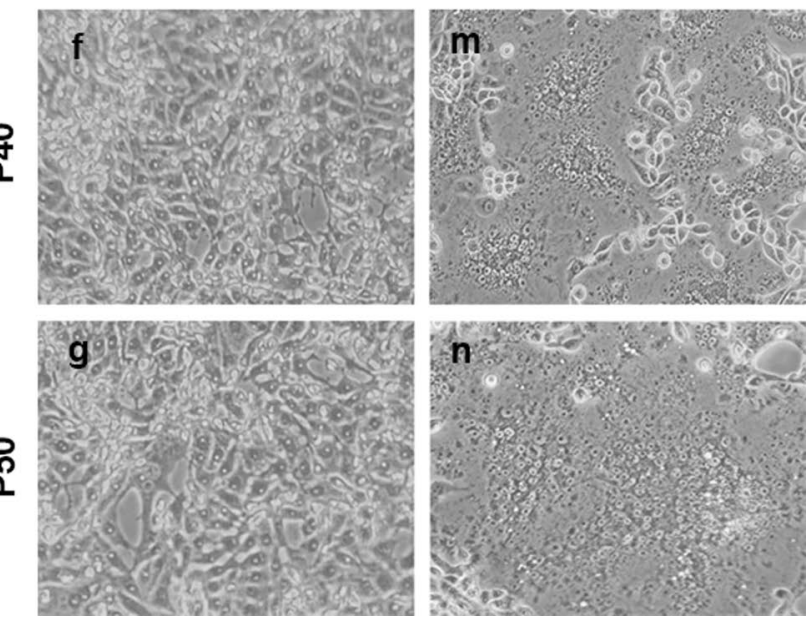


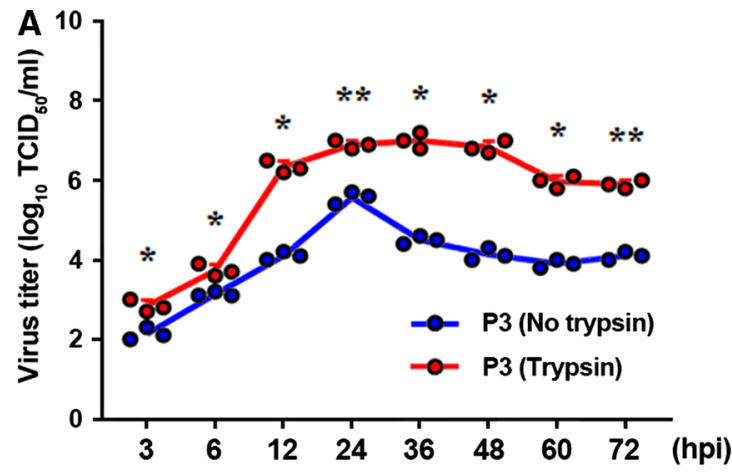

Fig. 9 One-step growth kinetics of SARS-CoV-2 strains passaged in the presence or absence of trypsin. Vero E6 cells were infected with each representative cell-adapted SARS-CoV-2 strain P3 (A) and P10 (B) and maintained in the presence or absence of $5 \mu \mathrm{g}$ of trypsin

the cell membrane, indicating that SARS-CoV-1 can enter cells via either an endosomal or non-endosomal pathway, depending on the presence of proteases [13]. Similarly, the present study showed trypsin-mediated augmentation of SARS-CoV-2 entry at the cell surface. Thus, like SARSCoV-1, SARS-CoV-2 can also exploit two different entry pathways, depending on the presence of trypsin. Moreover, the non-endosomal or direct entry of SARS-CoV-2 at the cell surface, mediated by trypsin, resulted in a $>1-\log$ more efficient infection than the endosomal entry pathway. Trypsin treatment before or during viral inoculation for 1 $\mathrm{h}$ failed to enhance infection. Thus, we conclude that the virus requires at least $1 \mathrm{~h}$ for trafficking from the cell surface to bind to ACE2, suggesting the involvement of trypsin in a post-attachment step (i.e., internalization). Given that protease-aided fusion occurred after the virus was bound to the cell surface, it appears that the binding of the $\mathrm{S}$ protein to ACE2 might cause a conformational change that allows fusion to be triggered by a subsequent protease cleavage.

SARS-CoV-2 can replicate in the respiratory (upper and lower) and gastrointestinal tracts [9]. The results of the present study imply that trypsin-like proteases secreted in the airways and the lungs might play a role in enhancing the replication of SARS-CoV-2 in those target organs, resulting in severe tissue damage. In particular, SARS-CoV-2 infection of pneumocytes could induce an inflammatory response that produces numerous proteases, some of which could enhance infection, resulting in a higher level of growth of SARS-CoV-2 in the lungs and therefore more tissue damage. Severe COVID-19 pneumonia accompanied by lung injury in COVID-19 patients is associated with high plasma concentrations of multiple cytokines, a so-called cytokine storm [31], and a higher rate of virus replication could contribute to the cytokine storm by destroying a larger number of infected cells. However, we found that elastase, a major protease generated during pneumonia, had no enhancing

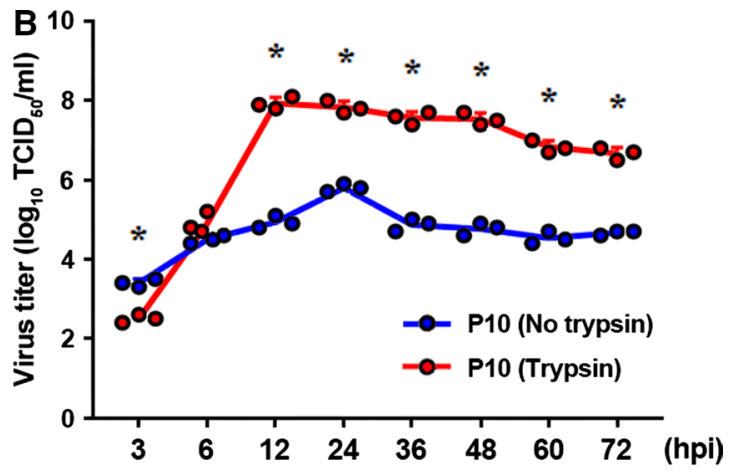

per $\mathrm{ml}$. At the indicated time points postinfection, culture supernatants were harvested, and virus titers were determined. Results are expressed as the mean of three independent experiments performed in triplicate, and error bars show the SDM. * $P<0.05$; **, $P<0.001$

effect on SARS-CoV-2 infection, in contrast to a previous study showing elastase-mediated enhancement of SARSCoV-1 infection [13]. This discrepancy might be attributable to the fact that a greater than tenfold higher concentration of elastase was used in that study compared to our study. In addition, it is possible that coinfection with non- or low-pathogenic bacteria in respiratory organs favors the production of proteases, which, in turn, results in severe lung illness in SARS-CoV-2-infected patients. Since underlying diseases play a critical role in severe COVID-19 illness in adults, certain medical conditions that dysregulate levels of trypsin or other proteases, such as chronic muco-obstructive lung diseases, might also be risk factors for poor outcomes in patients with SARS-CoV-2 infection [32, 33]. On the other hand, the small intestine, another major target organ, expresses ACE2 and TMPRSS2 and secretes a variety of proteases [10,34]. The presence of trypsin might also result in increased multiplication of SARS-CoV-2 in the small intestine, which could be associated with the high incidence rate of diarrhea in patients with COVID-19 [35].

We obtained cell-culture-adapted strains of SARS-CoV-2 by 50 passages in Vero E6 cells in the presence or absence of trypsin and assessed their phenotypic and genetic characteristics. A virological assay revealed that the cell-adapted viruses grown without trypsin grew comparably and caused CPE (cell rounding and clumping) similar to that induced by the parental virus in cultured cells. By contrast, the trypsin-adapted strains replicated more efficiently and produced larger syncytia than the P3(+) virus in Vero E6 cells. Moreover, SARS-CoV-2 strains passaged in the presence of trypsin showed a faster growth rate than those passaged in the absence of trypsin. Altogether, these findings indicated that the trypsin-adapted strains showed superior viral fitness in cultured cells and that trypsin supplementation positively influenced in vitro viral growth. 
Table 2 The number of nucleotide and amino acid differences between the parental KNU-SARS-CoV-2 P3 and cell-adapted viruses

\begin{tabular}{|c|c|c|c|c|c|c|c|c|c|c|c|}
\hline \multirow[t]{2}{*}{ UTR/ORF } & \multirow{2}{*}{$\begin{array}{l}\text { Encoded } \\
\text { protein }\end{array}$} & \multicolumn{10}{|c|}{ No. of nucleotide/amino acid changes (No. of amino acid deletions) } \\
\hline & & $\mathrm{P} 10\left(-^{\mathrm{a}}\right)$ & $\mathrm{P} 20(-)$ & P30(-) & $\mathrm{P} 40(-)$ & $\mathrm{P} 50(-)$ & $\mathrm{P} 10\left(+^{\mathrm{b}}\right)$ & $\mathrm{P} 20(+)$ & $\mathrm{P} 30(+)$ & $\mathrm{P} 40(+)$ & $\mathrm{P} 50(+)$ \\
\hline 5' UTR & & $-{ }^{c}$ & - & - & - & - & - & - & - & - & - \\
\hline \multirow[t]{11}{*}{ ORF1a } & nsp1 & - & - & $3 / 1^{\mathrm{d}}$ & $3 / 1$ & $3 / 1$ & - & - & - & - & - \\
\hline & nsp2 & - & - & - & - & - & - & - & - & - & - \\
\hline & nsp3 & - & - & - & - & - & - & - & - & - & - \\
\hline & nsp4 & - & - & - & - & - & - & - & $1 / 1$ & $1 / 1$ & - \\
\hline & nsp5 & - & - & - & - & - & - & - & $1 / 1$ & - & - \\
\hline & nsp6 & - & - & - & - & - & - & - & - & $1 / 1$ & $1 / 1$ \\
\hline & nsp7 & - & - & - & - & - & - & - & - & - & $1 / 0$ \\
\hline & nsp8 & - & - & - & - & - & - & - & - & - & - \\
\hline & nsp9 & - & - & - & - & - & - & - & - & - & - \\
\hline & nsp10 & - & - & - & - & - & - & - & - & - & - \\
\hline & nsp11 & - & - & - & - & - & - & - & - & - & - \\
\hline \multirow[t]{5}{*}{ ORF1b } & nsp12 & - & - & - & - & - & - & - & - & - & - \\
\hline & nsp13 & - & - & - & - & - & - & - & - & - & $1 / 1$ \\
\hline & nsp14 & - & - & - & - & - & - & - & - & - & - \\
\hline & nsp15 & - & - & - & - & - & - & - & - & - & - \\
\hline & nsp16 & - & - & - & - & - & - & - & - & - & - \\
\hline ORF2 & $\mathrm{S}$ & $2 / 2$ & $3 / 3$ & $5 / 5$ & $5 / 5$ & $5 / 5$ & $2 / 2$ & $6 / 5$ & $4 / 3$ & $4 / 3$ & $6 / 5$ \\
\hline ORF3a & ORF3a & - & - & - & - & - & - & - & - & - & - \\
\hline ORF4 & $\mathrm{E}$ & $1 / 1$ & $1 / 1$ & $1 / 1$ & $1 / 1$ & $1 / 1$ & - & - & - & - & - \\
\hline ORF5 & M & $1 / 1$ & $1 / 1$ & - & - & - & - & - & - & $1 / 1$ & $1 / 1$ \\
\hline ORF6 & ORF6 & - & - & - & - & - & $1 / 1$ & $1 / 1$ & $1 / 1$ & $1 / 1$ & $1 / 1$ \\
\hline ORF7a & ORF7a & - & - & - & - & - & - & - & - & - & - \\
\hline ORF7b & ORF7b & - & - & - & - & - & - & - & - & $4 / 13^{e}$ & $4 / 13$ \\
\hline ORF8 & ORF8 & - & - & - & - & - & - & - & $1 / 1$ & $1 / 1$ & $1 / 1$ \\
\hline ORF9 & $\mathrm{N}$ & $1 / 2^{\mathrm{f}}$ & $1 / 2$ & $1 / 2$ & $1 / 2$ & $1 / 2$ & - & - & - & - & - \\
\hline ORF10 & ORF10 & - & - & - & - & - & - & - & - & - & - \\
\hline 3' UTR & & - & - & - & - & - & - & - & - & - & - \\
\hline Total & & $\begin{array}{l}5 / 6 \\
(2)\end{array}$ & $\begin{array}{l}6 / 7 \\
(2)\end{array}$ & $\begin{array}{l}10 / 9 \\
(3)\end{array}$ & $\begin{array}{l}10 / 9 \\
(3)\end{array}$ & $\begin{array}{l}10 / 9 \\
(3)\end{array}$ & $3 / 3$ & $7 / 6$ & $8 / 7$ & $\begin{array}{l}13 / 21 \\
(13)\end{array}$ & $\begin{array}{l}16 / 23 \\
(13)\end{array}$ \\
\hline
\end{tabular}

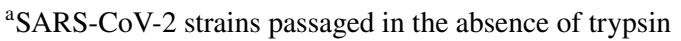

${ }^{\mathrm{b}} \mathrm{SARS}-\mathrm{CoV}-2$ strains passaged in the presence of trypsin

${ }^{\mathrm{c}}$ No mutations

${ }^{\mathrm{d}}$ Deletion of three nucleotides (ATG) covering the codon for one amino acid (methionine)

e Deletion of 13 amino acid residues by early termination due to a C92A substitution in ORF7b

${ }^{\mathrm{f}}$ Deletion of two amino acid resided by early termination due to a C1252T substitution in $\mathrm{N}$

We sequenced the entire genomes of the cell-cultureadapted strains to identify the genetic mutations that emerged during serial cell passage in the presence or absence of trypsin. Upon cell adaptation without trypsin addition, a total of six non-synonymous mutations arose, five of which were in the S gene. Interestingly, all cell-adapted P10(-) through P50(-) strains contained an R685S substitution in the S1/S2 FCS $\left({ }^{681} \mathrm{PRRAR}^{685}\right.$ ), changing this sequence to ${ }^{681}{ }^{6 R R A S}{ }^{685}$. Although biochemical studies are needed to investigate whether S proteins with the R685S mutation are cleaved, this mutation suggests that proteolytic priming of the $\mathrm{S}$ protein might be dispensable for virus replication in vitro. Considering that none of the P10(-) through P50(-) strains induced syncytia formation, the R685S mutation might make the S1/S2 FCS non-functional and, accordingly, prevent fusion at the plasma membrane. In addition to point mutations, we found two different DEL signatures in nsp1 and $\mathrm{N}$ of the cell-adapted strains grown without trypsin, suggesting that these DELs are associated with virus adaptation to the cell culture system in the absence of trypsin. 


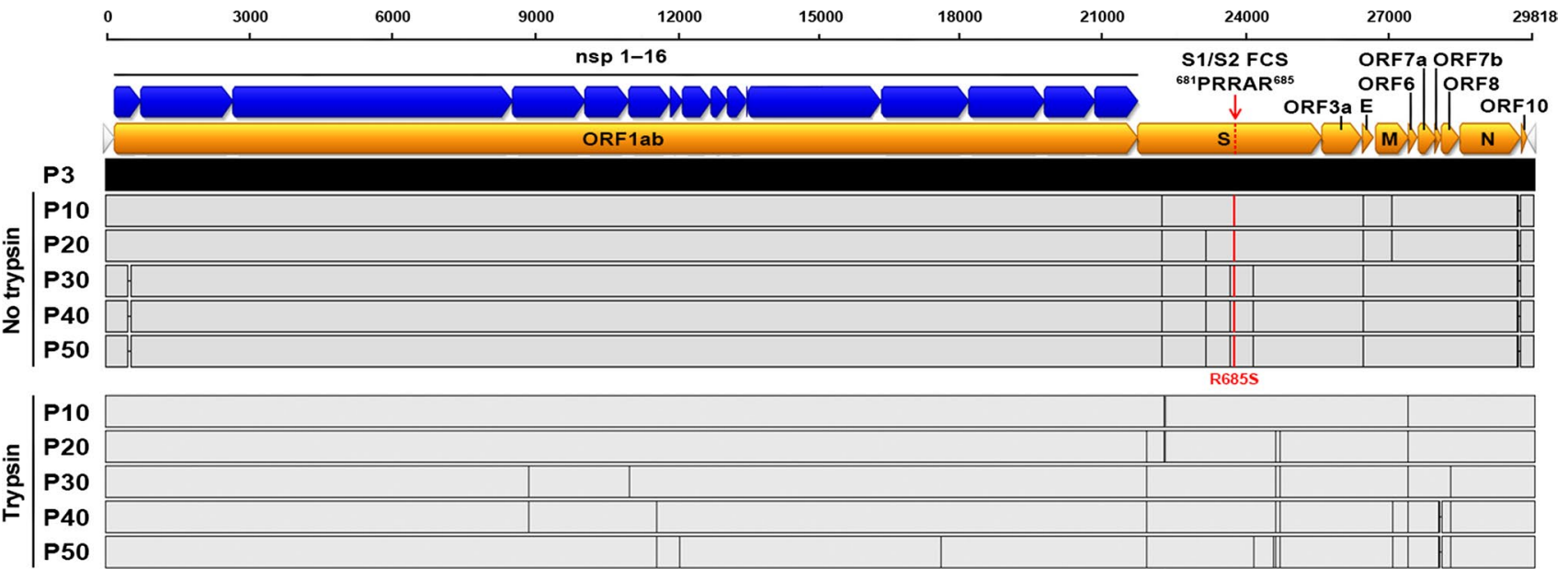

Fig 10 Schematic diagram of the amino acid differences between SARS-CoV-2 (P3) and its cell-adapted decedents (P10-P50). The organization of the SARS-CoV-2 genome, which is approximately $29.8 \mathrm{~kb}$ in length, is shown at the top. In the first diagram, blue arrows indicate the genes encoding nonstructural proteins (nsp1-16). In the second illustration, orange bars represent the identified ORFs. Light gray arrows represent the $5^{\prime}$ and $3^{\prime}$ untranslated regions. Lightly

During 50 cell passages in the presence of trypsin, a total of 20 non-synonymous mutations and 13 DELs were identified, all of which differed from those identified in the cell-adapted strains grown in the absence of trypsin. These results suggest that trypsin might have been relevant to the genetic modifications that occurred during in vitro growth. Unlike the P10(-) through P50(-) strains, all trypsinadapted $\mathrm{P} 3(+)$ through $\mathrm{P} 50(+)$ strains retained the intact S1/S2 FCS $\left({ }^{681}\right.$ PRRAR $\left.^{685}\right)$ in the $S$ protein. The $S$ protein induces fusion of the viral envelope with host cell membranes, and this fusion activity is most likely conferred by internal hydrophobic sequences in the $\mathrm{S} 2$ subunit $[36,37]$. The trypsin-adapted strains formed more extensive syncytia, leading to an increase in vacuolated areas, which were proportional to the number of cell culture passages. If the proteolytic cleavage of the S protein occurs within the functional S1/S2 FSC, mutations in S2 might be involved in the formation of syncytia by cells infected with the trypsinadapted virus. It is therefore notable that N960I and V961 A mutations were identified in $\mathrm{S} 2$ of the $\mathrm{P} 20(+)$ through to $\mathrm{P} 50(+)$ strains and that additional K849R and Q949R mutations emerged in the $\mathrm{S} 2$ fusion domain of $\mathrm{P} 50(+)$, suggesting that these genetic changes may contribute to cytopathology. Interestingly, the trypsin-adapted $\mathrm{P} 40(+)$ and $\mathrm{P} 50(+)$ viruses had a large 13-aa DEL in a short ORF7b protein composed of 43 aa residues. Although the precise role of this accessory protein is unknown, we cannot exclude the involvement of ORF7b in SARS-CoV-2 propagation in vitro. shaded areas are identical to those of SARS-CoV-2 (P3), and the vertical black bars represent individual amino acid positions where viruses from later passages differ from the P3 virus. Thin horizontal dashed lines indicate deletions. "S1/S2 FCS" represents the S1/S2 furin cleavage site (FCS), which contains multiple basic amino acids $\left({ }^{681} \mathrm{PRRAR}^{685}\right)$, and the vertical red bars indicate the R685S mutation in the S1/S2 FCS.

In conclusion, the present study showed that trypsin enhances the replication of SARS-CoV-2 in cultured cells and facilitates viral entry by promoting a direct fusion process at the cell surface. Our findings indicate that SARS$\mathrm{CoV}-2$ has the potential to use different pathways to enter cells, depending on the presence of trypsin. Remarkably, the trypsin-triggered SARS-CoV-2 non-endosomal entry at the cell surface facilitated more-efficient infection than the endosomal pathway in the absence of trypsin. Moreover, the Vero-E6-cell-adapted SARS-CoV-2 strains grown in the presence of trypsin exhibited clear syncytia formation and robust infection in cultured cells, whereas the strains without trypsin addition failed to form syncytia in infected cells and to enhance viral infection. These results suggest that trypsin or other proteases produced in the lungs or small intestine might enhance the replication of SARS-CoV-2 in these organs, leading to severe tissue damage. Conversely, these data may provide a practical methodology to improve the isolation and propagation of SARS-CoV-2 for the development of vaccines and other therapeutic agents. We also identified genetic mutations during serial in vitro passages in the presence or absence of trypsin that might be involved in the proteolytic priming or fusion activity of the S protein. Thus, our genetic data provide fundamental insights for future research involving reverse genetics to investigate the specific effect of mutations that occur during cell adaptation on SARS-CoV-2 replication and pathogenesis. 
Table 3 Summary of amino acid mutations during in vitro serial passages

\begin{tabular}{|c|c|c|c|c|c|c|c|c|c|c|c|c|c|}
\hline \multirow[t]{2}{*}{ ORF } & \multirow{2}{*}{$\begin{array}{l}\text { Encoded proteins } \\
\text { (aa length) }\end{array}$} & \multirow[t]{2}{*}{ aa position ${ }^{\mathrm{a}}$} & \multirow[b]{2}{*}{$\mathrm{P} 3$} & \multicolumn{10}{|c|}{ Mutation at the indicated passage number } \\
\hline & & & & $\mathrm{P} 10\left(-{ }^{\mathrm{b}}\right)$ & $\mathrm{P} 20(-)$ & $\mathrm{P} 30(-)$ & $\mathrm{P} 40(-)$ & P50(-) & $\mathrm{P} 10\left(+^{\mathrm{c}}\right)$ & $\mathrm{P} 20(+)$ & $\mathrm{P} 30(+)$ & $\mathrm{P} 40(+)$ & $\mathrm{P} 50(+)$ \\
\hline \multirow[t]{4}{*}{ ORF1a } & nsp1 (180) & 85 & M & & & DEL & DEL & DEL & & & & & \\
\hline & nsp4 (500) & 106 & $\mathrm{~L}$ & & & & & & & & $\mathrm{~F}$ & $\mathrm{~F}$ & \\
\hline & nsp5 (306) & 302 & G & & & & & & & & $\mathrm{R}$ & & \\
\hline & nsp6 (290) & 192 & M & & & & & & & & & $\mathrm{R}$ & $\mathrm{R}$ \\
\hline ORF1b & nsp13 (601) & 413 & $\mathrm{~T}$ & & & & & & & & & & I \\
\hline \multirow[t]{12}{*}{ ORF2 } & S (1273) & 68 & I & & & & & & & $\mathrm{R}$ & $\mathrm{R}$ & $\mathrm{R}$ & $\mathrm{R}$ \\
\hline & & 178 & $\mathrm{D}$ & $\mathrm{N}$ & $\mathrm{N}$ & $\mathrm{N}$ & $\mathrm{N}$ & $\mathrm{N}$ & & & & & \\
\hline & & 185 & $\mathrm{~K}$ & & & & & & $\mathrm{~N}$ & $\mathrm{~N}$ & & & \\
\hline & & 186 & $\mathrm{~F}$ & & & & & & $\mathrm{~V}$ & $\mathrm{~V}$ & & & \\
\hline & & 484 & $\mathrm{E}$ & & $\mathrm{D}$ & $\mathrm{D}$ & $\mathrm{D}$ & $\mathrm{D}$ & & & & & \\
\hline & & 655 & $\mathrm{H}$ & & & $\mathrm{Y}$ & $\mathrm{Y}$ & $\mathrm{Y}$ & & & & & \\
\hline & & 685 & $\mathrm{R}$ & $\mathrm{S}$ & $\mathrm{S}$ & $\mathrm{S}$ & $\mathrm{S}$ & $\mathrm{S}$ & & & & & \\
\hline & & 813 & S & & & I & I & I & & & & & \\
\hline & & 814 & $\mathrm{~K}$ & & & & & & & & & & $\mathrm{R}$ \\
\hline & & 949 & Q & & & & & & & & & & $\mathrm{R}$ \\
\hline & & 960 & $\mathrm{~N}$ & & & & & & & I & I & I & I \\
\hline & & 991 & V & & & & & & & $\mathrm{A}$ & $\mathrm{A}$ & $\mathrm{A}$ & $\mathrm{A}$ \\
\hline ORF4 & $\mathrm{E}(75)$ & 22 & A & V & V & V & $\mathrm{V}$ & $\mathrm{V}$ & & & & & \\
\hline ORF5 & M (222) & 125 & $\mathrm{H}$ & $\mathrm{Y}$ & $\mathrm{Y}$ & & & & & & & $\mathrm{Y}$ & $\mathrm{Y}$ \\
\hline ORF6 & ORF6 (61) & 2 & $\mathrm{~F}$ & & & & & & $\mathrm{~L}$ & $\mathrm{~L}$ & $\mathrm{~L}$ & $\mathrm{~L}$ & $\mathrm{~L}$ \\
\hline ORF7b & ORF7b (43) & $31-43$ & $S-A^{d}$ & & & & & & & & & DEL & DEL \\
\hline ORF8 & ORF8 (121) & 67 & S & & & & & & & & $\mathrm{F}$ & $\mathrm{F}$ & $\mathrm{F}$ \\
\hline ORF9 & N (419) & $418 / 419$ & QA & DEL & DEL & DEL & DEL & DEL & & & & & \\
\hline
\end{tabular}

${ }^{\mathrm{a}}$ Amino acid position numbering based on the genomic sequence of the SARS-CoV-2 P3 strain

${ }^{\mathrm{b}} \mathrm{SARS}-\mathrm{CoV}-2$ strains passaged in the absence of trypsin

${ }^{\mathrm{c}} \mathrm{SARS}-\mathrm{CoV}-2$ strains passaged in the presence of trypsin

${ }^{\mathrm{d}}$ Deleted amino acid residues SLELQDHNETCHA in ORF7b

Acknowledgements The pathogen resource (NCCP43326) for this study was provided by the National Culture Collection for Pathogens. This research was supported by the Basic Science Research Program through the National Research Foundation of Korea (NRF) funded by the Ministry of Education (NRF-2018R1D1A1B07040334).

Funding This research was supported by the Basic Science Program through the National Research Foundation of Korea (NRF) funded by the Ministry of Education (NRF-2018R1D1A1B07040334).

\section{Declarations}

Conflict of interest The authors declare that they have no conflict of interest.

Ethical approval All animal procedures were carried out in accordance with the guidelines established by the Institutional Animal Care and Use Committee.

\section{References}

1. Wang C, Horby PW, Hayden FG, Gao GF (2020) A novel coronavirus outbreak of global health concern. Lancet 395:470-473

2. Zhu N, Zhang D, Wang W, Li X, Yang B, Song J, Zhao X, Huang B, Shi W, Lu R, Niu P, Zhan F, Ma X, Wang D, Xu W, Wu G, Gao GF, Tan W (2020) A novel coronavirus from patients with pneumonia in China, 2019. N Engl J Med 382:727-733

3. Gorbalenya AE, Baker SC, Baric RS, Drosten C, Gulyaeva AA, Haagmans BL, Lauber C, Leontovich AM, Neuman BW, Penzar D, Perlman S, Poon LLM, Samborskiy DV, Sidorov IA, Sola I, Ziebuhr J (2020) The species severe acute respiratory syndromerelated coronavirus: classifying 2019-nCoV and naming it SARSCoV-2. Nat Microbiol 5:536-544

4. Kolahchi Z, De Domenico M, Uddin LQ, Cauda V, Grossmann I, Lacasa L, Grancini G, Mahmoudi M, Rezaei N (2021) COVID-19 and its global economic impact. Adv Exp Med Biol 1318:825-837

5. Zhou P, Yang XL, Wang XG, Hu B, Zhang L, Zhang W, Si HR, Zhu Y, Li B, Huang CL, Chen HD, Chen J, Luo Y, Guo H, Jiang RD, Liu MQ, Chen Y, Shen XR, Wang X, Zheng XS, Zhao K, Chen QJ, Deng F, Liu LL, Yan B, Zhan FX, Wang YY, Xiao GF, Shi ZL (2020) A pneumonia outbreak associated with a new coronavirus of probable bat origin. Nature 579:270-273 
6. Wu F, Zhao S, Yu B, Chen YM, Wang W, Song ZG, Hu Y, Tao ZW, Tian JH, Pei YY, Yuan ML, Zhang YL, Dai FH, Liu Y, Wang QM, Zheng JJ, Xu L, Holmes EC, Zhang YZ (2020) A new coronavirus associated with human respiratory disease in China. Nature 579:265-269

7. Shang J, Wan Y, Luo C, Ye G, Geng Q, Auerbach A, Li F (2020) Cell entry mechanisms of SARS-CoV-2. Proc Natl Acad Sci USA 117:11727-11734

8. Wang Q, Zhang Y, Wu L, Niu S, Song C, Zhang Z, Lu G, Qiao C, Hu Y, Yuen KY, Wang Q, Zhou H, Yan J, Qi J (2020) Structural and functional basis of SARS-CoV-2 entry by using human ACE2. Cell 181:894-904

9. Neerukonda SN, Katneni U (2020) A review on SARS-CoV-2 virology, pathophysiology, animal models, and anti-viral interventions. Pathogens 9:426

10. Hoffmann M, Kleine-Weber H, Schroeder S, Krüger N, Herrler T, Erichsen S, Schiergens TS, Herrler G, Wu Nh, Nitsche A, Müller MA, Drosten C, Pöhlmann S (2020) SARS-CoV-2 cell entry depends on ACE2 and TMPRSS2 and is blocked by a clinically proven protease inhibitor. Cell 181:271-280

11. Matsuyama S, Nao N, Shirato K, Kawase M, Saito S, Takayama I, Nagata N, Sekizuka T, Katoh H, Kato F, Sakata M, Tahara M, Kutsuna S, Ohmagari N, Kuroda M, Suzuki T, Kageyama T, Takeda M (2020) Enhanced isolation of SARS-CoV-2 by TMPRSS2expressing cells. Proc Natl Acad Sci USA 117:7001-7003

12. Bertram S, Glowacka I, Müller MA, Lavender H, Gnirss K, Nehlmeier I, Niemeyer D, He Y, Simmons G, Drosten C, Soilleux EJ, Jahn O, Steffen I, Pöhlmann S (2011) Cleavage and activation of the severe acute respiratory syndrome coronavirus spike protein by human airway trypsin-like protease. J Virol 85:13363-13372

13. Matsuyama S, Ujike M, Morikawa S, Tashiro M, Taguchi F (2005) Protease-mediated enhancement of severe acute respiratory syndrome coronavirus infection. Proc Natl Acad Sci USA 102:12543-12547

14. Menachery VD, Dinnon KH III, Yount BL Jr, McAnarney ET, Gralinski LE, Hale A, Graham RL, Scobey T, Anthony SJ, Wang L, Graham B, Randell SH, Lipkin WI, Baric RS (2020) Trypsin treatment unlocks barrier for zoonotic bat coronavirus infection. J Virol 94:e01774-e1819

15. Yang YL, Meng F, Qin P, Herrler G, Huang YW, Tang YD (2020) Trypsin promotes porcine deltacoronavirus mediating cell-to-cell fusion in a cell type-dependent manner. Emerg Microbes Infect 9:457-468

16. Hofmann M, Wyler R (1988) Propagation of the virus of porcine epidemic diarrhea in cell culture. J Clin Microbiol 26:2235-2239

17. Hu H, Jung K, Vlasova AN, Chepngeno J, Lu Z, Wang Q, Saif LJ (2015) Isolation and characterization of porcine deltacoronavirus from pigs with diarrhea in the United States. J Clin Microbiol 53:1537-1548

18. Jang G, Kim SH, Lee YJ, Kim S, Lee KK, Lee C (2018) Isolation and characterization of Korean porcine deltacoronavirus strain KNU16-07. J Vet Sci 19:577-581

19. Lee S, Kim Y, Lee C (2015) Isolation and characterization of a Korean porcine epidemic diarrhea virus strain KNU-141112. Virus Res 208:215-224

20. Zhou P, Fan H, Lan T, Yang XL, Shi WF, Zhang W, Zhu Y, Zhang YW, Xie QM, Mani S, Zheng XS, Li B, Li JM, Guo H, Pei GQ, An XP, Chen JW, Zhou L, Mai KJ, Wu ZX, Li D, Anderson DE, Zhang LB, Li SY, Mi ZQ, He TT, Cong F, Guo PJ, Huang R, Luo Y, Liu XL, Chen J, Huang Y, Sun Q, Zhang XLL, Wang YY, Xing SZ, Chen YS, Sun Y, Li J, Daszak P, Wang LF, Shi ZL, Tong YG, Ma JY (2018) Fatal swine acute diarrhoea syndrome caused by an HKU2-related coronavirus of bat origin. Nature 556:255-258
21. Kim JM, Chung YS, Jo HJ, Lee NJ, Kim MS, Woo SH, Park S, Kim JW, Kim HM, Han MG (2020) Identification of coronavirus isolated from a patient in Korea with COVID-19. Osong Public Health Res Perspect 11:3-7

22. Lee S, Son KY, Noh YH, Lee SC, Choi HW, Yoon IJ, Lee C (2017) Genetic characteristics, pathogenicity, and immunogenicity associated with cell adaptation of a virulent genotype 2b porcine epidemic diarrhea virus. Vet Microbiol 207:248-258

23. Pan X, Kong N, Shan T, Zheng H, Tong W, Yang S, Li G, Zhou E, Tong G (2015) Monoclonal antibody to N protein of porcine epidemic diarrhea virus. Monoclon Antib Immunodiagn Immunother 34:51-54

24. Lee YJ, Lee C (2012) Stress-activated protein kinases are involved in porcine reproductive and respiratory syndrome virus infection and modulate virus-induced cytokine production. Virology 427:80-89

25. Reed LJ, Muench H (1938) A simple method for estimating fifty percent endpoints. Am J Epidemiol 27:493-497

26. Jeon JH, Lee C (2021) Stress-activated protein kinases are involved in the replication of porcine deltacoronavirus. Virology 559:196-209

27. Sagong M, Lee C (2011) Porcine reproductive and respiratory syndrome virus nucleocapsid protein modulates interferon- $\beta$ production by inhibiting IRF3 activation in immortalized porcine alveolar macrophages. Arch Virol 156:2187-2195

28. Lee YN, Lee C (2013) Complete genome sequence of a novel porcine parainfluenza virus 5 isolate in Korea. Arch Virol 158:1765-1772

29. Millet JK, Whittaker GR (2015) Host cell proteases: critical determinants of coronavirus tropism and pathogenesis. Virus Res 202:120-134

30. Yan R, Zhang Y, Li Y, Xia L, Guo Y, Zhou Q (2020) Structural basis for the recognition of SARS-CoV-2 by full-length human ACE2. Science 367:1444-1448

31. Huang C, Wang Y, Li X, Ren L, Zhao J, Hu Y, Zhang L, Fan G, Xu J, Gu X, Cheng Z, Yu T, Xia J, Wei Y, Wu W, Xie X, Yin W, Li H, Liu M, Xiao Y, Gao H, Guo L, Xie J, Wang G, Jiang R, Gao Z, Jin Q, Wang J, Cao B (2020) Clinical features of patients infected with 2019 novel coronavirus in Wuhan, China. Lancet 395:497-506

32. Javanmardi F, Keshavarzi A, Akbari A, Emami A, Pirbonyeh N (2020) Prevalence of underlying diseases in died cases of COVID-19: A systematic review and meta-analysis. PLoS ONE 15:e0241265

33. Carroll EL, Bailo M, Reihill JA, Crilly A, Lockhart JC, Litherland GJ, Lundy FT, McGarvey LP, Hollywood MA, Martin SL (2021) Trypsin-like proteases and their role in muco-obstructive lung diseases. Int J Mol Sci 22:5817

34. Gu J, Han B, Wang J (2020) COVID-19: gastrointestinal manifestations and potential fecal-oral transmission. Gastroenterology 158:1518-1519

35. D'Amico F, Baumgart DC, Danese S, Peyrin-Biroulet L (2020) Diarrhea during COVID-19 infection: pathogenesis, epidemiology, prevention, and management. Clin Gastroenterol Hepatol 18:1663-1672

36. Lai AL, Millet JK, Daniel S, Freed JH, Whittaker GR (2017) The SARS-CoV fusion peptide forms an extended bipartite fusion platform that perturbs membrane order in a calciumdependent manner. J Mol Biol 429:3875-3892

37. Lee C (2015) Porcine epidemic diarrhea virus: an emerging and re-emerging epizootic swine virus. Virol J 12:1-16

Publisher's Note Springer Nature remains neutral with regard to jurisdictional claims in published maps and institutional affiliations. 